Espaço Aberto | Open Space

\title{
Ações afirmativas no ensino superior e povos indígenas no Brasil: uma trajetória de trabalho
}

\begin{abstract}
Affirmative action in higher education and indigenous peoples in Brazil: a trajectory
\end{abstract}

Antonio Carlos de Souza Lima*

* Museu Nacional/Universidade Federal do Rio de Janeiro - Rio de Janeiro, RJ, Brasil acslima@mn.ufrj.br 


\title{
Resumo
}

Este texto apresenta um relato, à guisa de depoimento, da trajetória de um projeto de intervenção desenvolvido por uma equipe de pesquisadores vinculados ao Laboratório de Pesquisas em Etnicidade, Cultura e Desenvolvimento/Departamento de Antropologia/Museu Nacional-Universidade Federal do Rio de Janeiro no fomento a ações afirmativas para o acesso, permanência e sucesso educacional de estudantes indígenas no ensino superior. A equipe do Laced/MN-UFRJ que desenvolveu tais atividades pensou-as à luz da antropologia e de estar institucionalmente baseada numa instituição de ensino superior voltada para a pesquisa e a pós-graduação. O período abarcado é, grosso modo, aquele da primeira década do século XXI. O texto busca recuperar e documentar as condições de possibilidade que facultaram tal intervenção, financiada com recursos da Fundação Ford, e em relação direta com as lutas por ações afirmativas no ensino superior movidas pelo(s) movimento(s) negro(s), caracterizando-a como marcada pela percepção das demandas essenciais para os povos indígenas por terra e sustentabilidade. Narram-se as formas como a equipe do Laced procedeu à indução da demanda de recursos por universidades disponíveis a desenvolverem ações afirmativas para indígenas, a disseminação do debate em torno dessas ações, as articulações para que fossem desenvolvidas políticas governamentais que as fomentassem a mais longo prazo, os conhecimentos e documentos gerados nesse processo.

Palavras-chave: povos indígenas; ações afirmativas; ensino superior; Fundação Ford.

\begin{abstract}
This paper presents an account, or testimony, of the trajectory of a project developed by a team of researchers associated with the Research Laboratory on Ethnicity, Culture and Development/Department of Anthropology/National Museum-Federal University of Rio de Janeiro that promoted affirmative action policies for access, retention and educational success of indigenous students in higher education in the first decade of the twenty-first century. The Laced/MN-UFRJ team conceived these efforts in dialogue with anthropology, based on a perception that it was carrying out this project in an institution of higher education focused on research and graduate studies. The paper seeks to recover and document the conditions that made this intervention possible. Funded by the Ford Foundation and building on the struggles of black movement organizations for affirmative action in higher education, these actions were based on the perception that demands for land and sustainability are essential for Indigenous Peoples. The paper describes how the Laced team helped universities to develop affirmative action policies for indigenous peoples, how these actions were disseminated and debated, how government policies were developed to sustain affirmative action in the long term, as well as what knowledge and documents were generated by this process.
\end{abstract}

Keywords: indigenous peoples; affirmative action; higher education; Ford Foundation. 
A possibilidade de integrar este volume com uma reflexão sobre minha experiência com a concepção e a implantação de programas para ações afirmativas visando à presença de indígenas no ensino superior, e de fazê-lo numa chave autoetnográfica, colocou-me diversos desafios. ${ }^{1}$

O primeiro desses desafios (aliás, desafios foi uma palavra recorrente em tudo que produzimos a respeito) refere-se ao fato de que, desde 2003, acompanhei e intervi na discussão e proposição de medidas para o acesso, a permanência e uma bem-sucedida finalização de estudantes indígenas em universidades, o que se deu em função de ter desenvolvido e coordenado o Projeto Trilhas de Conhecimentos: o Ensino Superior de Indígenas no Brasil (PTC), desenvolvido em duas etapas (2004-2007; 2007-2009). Além do PTC, desenvolvi outros dois projetos voltados para o mesmo campo temático, intitulados Educação Diferenciada, Gestão Territorial e Intervenções Desenvolvimentistas. Pesquisa, Sistematização de Conhecimentos, Produção de Material Didático (2009-2011) e Educação Superior de Indígenas no Brasil: Avaliação, Debate, e Qualificação (2011-2015). ${ }^{2}$

Nosso enfoque da questão do ensino superior para indígenas e os projetos de pesquisa e intervenção a ela relacionados estão documentados em material já publicado (Souza Lima, 2007, 2008, 2016; Souza Lima; Barroso, 2013a; Souza Lima; Barroso-Hoffmann, 2007; Souza Lima; Paladino, 2012a, 2012b; Vianna et al., 2014, dentre outros) ou em vídeos (Educação..., 2015; Trilhas..., 2007). Minha experiência relativamente recente de escrita de um memorial para a promoção à classe E (professor titular) da carreira docente das instituições federais de ensino superior me fez ter de lidar de algum modo com uma chave descritiva semelhante, assim como com a sensação de que estou repetindo o já escrito em outros textos, de estar me autoplagiando ou, na melhor das hipóteses, me "parafraseando".

$\mathrm{O}$ uso da primeira pessoa do singular, ainda que meramente sociológico, assim como uma espécie de sobrevalorização da subjetividade do pesquisador e de suas emoções diante do universo pesquisado, mais comuns em

1 Agradeço a Ruben Oliven pelo honroso convite para participar deste $50^{\circ}$ número de Horizontes Antropológicos, esperando que, com este trabalho, eu esteja modestamente à sua altura. Agradeço a Maria Macedo Barroso pela providencial interlocução - também aqui - ao longo da elaboração do texto. Agradeço, também, à Roberta Ceva pelo trabalho de revisão e de normalização do texto entregue por mim.

2 Para o site remanescente dessa experiência, ver http://www.trilhasdeconhecimentos.etc.br/ (acessado em 07/09/2017). 
antropologia após a voga pós-moderna, me geram certo desconforto. Nada contra. Quem interage comigo cotidianamente sabe que estou longe de ser "desafetado", ou de crer na possibilidade de um "objetivismo absoluto", até muito pelo contrário. Mas a vivência de muitos anos de psicanálise me faz crer que apenas uma dimensão muito pequena e estilisticamente muito controlada, e por vezes pouco elucidativa, dos princípios analíticos e pessoais, dos sentimentos que guiam o investigador e lhe conferem uma percepção mais ou menos profunda do que faz, é textualmente materializada e "revelada" nessas investidas de "exposição/exibição (controlada) de si".

Por outro lado, considero de extrema importância precisar certas condições sociais de produção que se espraiam a partir de um "eu" pesquisador, já que elas são imprescindíveis para o entendimento de cada análise apresentada, um movimento que não deve tomar o lugar da análise em si mesma. No caso específico de minha experiência com a questão abordada neste texto, seria de todo infundado atribuir às equipes que liderei ao longo desse período um papel solitário na luta por políticas governamentais e institucionais voltadas para o fomento da presença indígena no ensino superior. De meu ponto de vista, atuamos como parte de um conjunto mais amplo de atores (indígenas e não indígenas, docentes universitários e gestores governamentais, e de uma organização filantrópica específica, a Fundação Ford - doravante FF). Contudo, procuramos conscientemente propiciar movimentos e iniciativas, interpretações e propostas de ação, além de pôr em comunicação duas direções até então pouco conectadas: a que preconizava a criação de licenciaturas interculturais indígenas visando à formação de professores e a que propunha um conjunto de intervenções que facilitasse a presença de indígenas em cursos universitários regulares e/ou a criação de novos cursos. ${ }^{3}$

Esse papel de propiciadores foi uma escolha pensada, dada a singularidade da posição do Museu Nacional, instituição que por definição estatutária não pode ter cursos de graduação, o que me colocava até certo ponto "fora" do problema sobre o qual procuraria intervir. No campo da antropologia, o museu é conhecido por abrigar o Programa de Pós-Graduação em Antropologia Social (PPGAS), criado em 1968, o que implica a necessidade da pesquisa em qualquer

3 Agradeço a Maria Macedo Barroso por ter me chamado a atenção e lembrado da novidade de nossa atuação nessa junção do que pareciam ser caminhos que seguiriam sem intersecções. Veja-se, para tanto, Barroso (2013). 
intervenção. Some-se a isso o fato de estar sediado numa universidade especialmente refratária, naquele momento, à abertura de cotas no acesso ao ensino superior ou outras ações afirmativas. Assim, reivindicar o papel de "paladino(s) de uma causa" (com o qual não simpatizo em absoluto, ainda que jamais tenha sido um problema para mim participar de causas) soava inadequado, senão fraudulento. Exercer de modo consistente esse papel implicaria mergulhar a fundo na discussão da ampla área da educação e dialogar com a extensa produção da sociologia da educação.

Hoje, há muito produzido sobre ações afirmativas, embora ainda haja muito a ser dito. Como relatarei abaixo, não chegamos a esse problema social pela via da investigação científica, nem tampouco, como se deu com muita frequência no caso das cotas raciais, pelo debate essencialmente político de uma demanda do movimento social. Na vida prática, eu estava engajado em linhas de pesquisa já delimitadas, com alunos e projetos a ela vinculados. Por outro lado, acreditava, e ainda acredito, que é preciso que os próprios indígenas se engajem na busca por mudanças nas universidades que já procuravam acessar em meados/finais dos anos 1990, assim como é fundamental que os docentes e os quadros técnicos dessas universidades adquiram conhecimentos sobre os povos indígenas, ultrapassando os arraigados preconceitos tão fortemente encravados no arquivo colonial de imagens que ainda hoje pauta o senso comum sobre os indígenas no país. Somente dessa maneira, pensávamos, seria possível imaginar formas de tornar os cursos universitários regulares mais úteis aos alunos indígenas, ou criar cursos novos a eles direcionados. Para tanto, era sobretudo importante que os governos federais se apercebessem dessas dimensões e passassem a investir em ações afirmativas de diversas ordens. Sem essas condições, nos parecia que o tipo de investimento que fizemos de nada serviria e que todos os recursos e trabalho empenhados seriam inúteis.

Por todas essas perspectivas e razões, mantivemos a preocupação de documentar permanentemente toda a nossa atuação e produzir conhecimentos sobre um debate social em configuração. Os conhecimentos assim acumulados merecem ser revisitados nesse momento da história brasileira em que inúmeras políticas sociais estão senão em desconstrução, profundamente ameaçadas, como estão os próprios rumos da universidade pública e gratuita brasileira, responsável pela reprodução, com recursos arrecadados pela administração federal, das elites nacionais durante a maior parte da história do Brasil republicano. 
Retraço a seguir aspectos dessa trajetória. Procederei aqui a uma espécie de leitura interessada de certas dimensões e sinalizarei quando for o caso de haver outros trabalhos publicados sobre os pontos abordados. ${ }^{4}$

Não tenho a intenção de cobrir com igual atenção todo o período de 2002, quando nos envolvemos mais diretamente com o início do delineamento do que viria a ser o Trilhas de Conhecimentos, até agosto de 2015, quando, já na presidência da Associação Brasileira de Antropologia, concluí minha participação no grupo de trabalho, criado pela portaria $\mathrm{n}^{\circ}$ 52, de 24 de janeiro de 2014 (Brasil, 2014a, p. 10) “[...] com a finalidade de realizar estudos sobre a criação de instituição de educação superior intercultural indígena que promova, por meio do ensino, pesquisa e extensão, atividades voltadas para a valorização dos patrimônios epistemológicos, culturais e linguísticos dos povos indígenas, considerando-se suas demandas e necessidades", ao colaborar para a finalização de um documento que propôs formas de estabelecimento de ações em rede entre universidades federais e institutos federais de tecnologia para a criação, com recursos federais, de núcleos articulados em rede responsáveis por promover a transformação das instituições federais de ensino superior e tecnológico para que facilitassem e apoiassem a presença de alunos indígenas, assim como de uma proposta de uma universidade intercultural indígena. De agosto de 2015 para cá, todos sabemos o que tem se passado.

Tampouco pretendo produzir uma análise que sintetize as diversas ações federais no mesmo período. Em alguns trabalhos procurei enfocar esse panorama e disponibilizar resultados de seminários de avaliação e debate. ${ }^{5}$ Muito aconteceu, e muito mais poderia (e deveria) ter acontecido, pois alguns dos problemas básicos - sobretudo o enfrentamento da diferença dos custos para alunos indígenas (assim como para quilombolas e outros povos tradicionais com direitos sobre áreas de terras) que se deslocam de suas aldeias para as cidades

4 Em Souza Lima (2013), Souza Lima e Barroso (2013b) e Barroso (2013) encontram-se textos mais densos sobre essas questões, em especial no período 2004-2008. Os outros textos de Souza Lima e Barroso (2013a) cobrem outros aspectos desse campo de intervenções não menos importantes.

5 Para trabalhos nessa direção, ver Souza Lima (2016). Para um vídeo gerado sobre a temática, ver Educação superior de indígenas no Brasil (2015), também acessível via o site do Laboratório de Pesquisas em Etnicidade Cultura e Desenvolvimento (Laced), setor de Etnologia e Etnografia, Departamento de Antropologia/Museu Nacional-Universidade Federal do Rio de Janeiro, do qual sou integrante e um dos coordenadores, pelo link http://laced.etc.br/site/galeria/videos/ (acessado em 07/09/2017). 
para estudar, em face daqueles que já estão nas cidades - só foram parcialmente enfrentados com a chamada "Bolsa Permanência". ${ }^{6}$

Afinal, durante todo esse período em que trabalhamos, enfatizamos que as cotas, ou seja, dispositivos de acesso às universidades, ainda que extremamente importantes, não resolviam toda a questão, sobretudo para os povos indígenas: a pauta da luta pela diversidade não era nem é a mesma da luta por inclusão; a presença indígena nas universidades coloca problemas epistemológicos e conceituais de outra natureza que aqueles pautados pela inclusão, e é exatamente aí que está posto o desafio a indígenas e não indígenas. Assim, os caminhos para a equidade como meta são bastante distintos. ${ }^{7}$

Se a Bolsa Permanência é um exemplo de uma reivindicação fundamental de estudantes em situação menos favorecida, a inexistência de bolsas diferenciadas para a pós-graduação é exemplo do que não foi feito: quando o Professor André Luiz de Figueiredo Lázaro saiu do cargo de secretário de Educação Continuada, Alfabetização e Diversidade, no Ministério da Educação (MEC), ao final do segundo mandato de Luiz Inácio Lula da Silva, em dezembro de 2010, deixara negociado com o então presidente da Fundação Coordenação de Aperfeiçoamento do Pessoal de Nível Superior (Capes), Professor Jorge Guimarães, a implantação de um programa de bolsas específicas no nível de mestrado e de doutorado para ações afirmativas para indígenas e negros, tendo assegurado inclusive o repasse de recursos, o que foi simplesmente desconsiderado pela agência após a sua saída. ${ }^{8}$

6 O Programa Bolsa Permanência foi criado pela portaria ${ }^{\circ}$ 389, de 9 de maio de 2013 (Brasil, 2013a). O programa “[...] é uma ação do Governo Federal de concessão de auxílio financeiro a estudantes matriculados em instituições federais de ensino superior em situação de vulnerabilidade socioeconômica e para estudantes indígenas e quilombolas. O recurso é pago diretamente ao estudante de graduação por meio de um cartão de benefício". Ver http://permanencia. mec.gov.br/ (acessado em 07/09/2017).

7 Ver Souza Lima $(2007,2012)$ e Baniwa (2013).

8 André Luiz de Figueiredo Lázaro é graduado em Letras, mestre e doutor em Comunicação e professor adjunto da Escola de Comunicação da Universidade do Estado do Rio de Janeiro (UERJ), da qual foi diretor. Foi sub-reitor de Extensão durante a gestão como reitora da UERJ de Nilcéa Freire - que foi, em seguida, ministra da Secretaria Especial de Políticas para as Mulheres de 2004 a 2010 e representante da Fundação Ford no Brasil de 2011 a 2015 - período no qual teve início a implantação da política de cotas na instituição. De 2004 a 2006, foi secretário executivo adjunto do MEC e, de 2006 a 2010, secretário da Secretaria de Educação Continuada, Alfabetização e Diversidade (Secad). Hoje está vinculado à UERJ e à Faculdade Latino-Americana de Ciências Sociais (Flacso), onde desenvolve desde 2013 o projeto Grupo Estratégico de Análise da Educação Superior no Brasil II, financiado pela FF. 
Focarei minha atenção sobretudo nos anos preparatórios e iniciais do Trilhas de Conhecimentos, sem ter a pretensão de fazer um relato exaustivo (e extenuante) de atividades. Se sobre parte do que está aqui já pude escrever, há uma parte ponderável na qual não cheguei a tocar. E há muito mais que poderia ser dito, mas para que não o seja em tom de "relatório de atividades" é preciso mais tempo, mais trabalho e mais páginas. Assim, alternarei as primeiras pessoas do singular e do plural não pelo uso do chamado "plural de modéstia": ao traçar essa trajetória, não imagino que ela tenha sido possível sem o enredamento de um amplo conjunto de pessoas e instituições, e sem perceber que atuamos dentro de um cenário muito mais amplo de agentes e agências em interlocução, que teve seu centro de fato na forma como os povos indígenas se apropriaram das políticas governamentais a eles dirigidas no pós-Constituinte, em especial as de educação. Tampouco é possível entender todo esse cenário sem se ter em mente a luta pelas ações afirmativas nas universidades federais e estaduais, bem como a considerável expansão - após um período de estase e "morte lenta" - do sistema universitário federal e do sistema de institutos federais de tecnologia.

Creio que, no momento em que vivemos, no qual vemos muitas das ações surgidas nessa primeira década e meia dos anos 2000, ainda que bastante imperfeitas e com muito a se corrigir, avaliar e repropor, ameaçadas em sua implementação pela simples inexistência de recursos financeiros para tanto, é importante registrar o que se obteve, de modo a desenhar oportunamente outros futuros possíveis.

\section{Das terras indígenas ao primeiro desenho do Trilhas de Conhecimentos}

De 1985 a 1993, João Pacheco de Oliveira coordenou no Museu Nacional o Projeto Estudo sobre Terras Indígenas no Brasil: Invasões, Uso do Solo e Recursos Naturais (Peti), financiado pela Fundação Ford, cuja relação com a renovação e a estruturação da moderna área das ciências sociais no Brasil é bastante conhecida. ${ }^{9}$ O Peti teve uma importante produção, que serviu tanto aos deba-

9 Para alguns aspectos desse processo, ver Miceli (1993) e Brooke (2002). 
tes entretecidos na Assembleia Nacional Constituinte quanto para a posterior reestruturação dos processos de reconhecimento de direitos territoriais indígenas. Esse projeto, do qual fui subcoordenador, e durante o qual realizei a pesquisa que resultou em minha tese de doutorado, defendida em 1992, e fiz concurso para professor assistente de Etnologia em 1988, passando a integrar o Departamento de Antropologia como docente no final de 1989, ensejou outros desdobramentos sob orientação de João Pacheco de Oliveira e uma sólida linha de investigação sobre processos de territorialização e outras questões. ${ }^{10} \mathrm{O}$ projeto foi concluído, em larga medida, por uma reorientação de linhas de financiamento da própria FF, sem que parte de sua produção mais substantiva fosse publicada sob a forma de livro. No ano de 1998, decidimos (João Pacheco de Oliveira e eu) solicitar uma pequena quantia para dar suporte à publicação de alguns livros. Encontramos no escritório da fundação no Rio de Janeiro José Gabriel Lopez, assessor de programa (PO - Program Officer para usar a "categoria nativa") da área de Desenvolvimento Sustentável da fundação, recém-chegado ao Brasil, que nos contrapropôs realizar um survey sobre o cenário de políticas indigenistas e indígenas, realizar um seminário de avaliação de resultados e elaborar um relatório que fornecesse elementos para recomendações de financiamento, além de recursos para publicações.

Não sem certa hesitação, acabamos por aceitar. ${ }^{11}$ João Pacheco, Marcelo Piedrafita Iglesias e Bruno Pacheco de Oliveira realizaram um amplo esforço de pesquisa, documentação (inclusive em vídeo) e articulação com as organizações

10 Ver Pacheco de Oliveira $(1987,1998,1999,2004)$.

11 Naquele momento, havia sido convidado a aplicar e tivera meu nome apresentado e aprovado para ser o primeiro "bolseiro luso-afro-brasileiro" do Instituto de Ciências Sociais (ICS), da Universidade de Lisboa, e com esses recursos acompanhar a equipe de Cristiana Bastos à Índia, mais especificamente ao estado de Goa, o que aconteceria de inícios de novembro de 1998 até meados de janeiro de 1999. Minha intenção era iniciar uma pesquisa sobre a formação de administradores coloniais no que atualmente é o Instituto Superior de Ciências Sociais e Políticas, hoje integrado à Universidade de Lisboa (ISCSP). Essa era também a possibilidade de um período pós-doutoral no ICS, uma notável instituição que vivia então o seu auge. Anos depois, passei o material que havia coligido sobre o ISCSP para Carla Suzana Além Abrantes, que foi minha orientanda no mestrado e no doutorado (período no qual teve uma bolsa sanduíche da Capes junto ao ICS sob a orientação de Cristiana Bastos, coorientadora da tese), e desenvolveu interesses próprios e uma extensa pesquisa, hoje atuando como docente na Unilab, em Redenção, no Ceará. O tema da formação de elites indígenas já estava aí desenhado. 
indígenas. ${ }^{12}$ Meu trabalho focou as políticas indigenistas que se desdobraram como políticas indigenistas diferenciadas no período pós-Constituinte para a saúde, a educação e a sustentabilidade, além da própria política fundiária na sua interface mais organizacional. Estávamos no final do primeiro mandato de Fernando Henrique Cardoso, iniciava-se o segundo, e efetivamente começavam a ser implantadas as novas políticas indigenistas. Implantava-se o Projeto Integrado de Proteção às Populações e Terras Indígenas da Amazônia Legal (PPTAL), sob o qual as grandes demarcações de terras indígenas na região amazônica foram implementadas. O PPTAL era um subcomponente do Programa Piloto para a Proteção das Florestas Tropicais do Brasil (PPG7), grande intervenção na área (socio)ambiental brasileira a partir de fundos do Grupos dos 7, da gerência do Banco Mundial e da ação de vigilância pedagógico-disciplinar sobre a administração pública da cooperação técnica internacional para o desenvolvimento, especialmente (mas não só) alemã, através da Sociedade Alemã para a Cooperação Técnica - Deutsche Gesellschaft für Technische Zusammenarbeit GTZ, hoje Deutsche Gesellschaft für Internationale Zusammenarbeit GIZ, ou Sociedade para Cooperação Internacional. Se as organizações indígenas, sobretudo na Amazônia, estavam em plena efervescência, a cooperação parecia ser onipresente e pretender "terraformar" a administração pública. A tutela parecia estar desbotando, ultrapassada pelos novos tempos. ${ }^{13}$

Tomando como base o levantamento que fizemos tanto para as políticas indígenas quanto para as indigenistas, organizamos o seminário Bases para uma Nova Política Indigenista, realizado nos dias 28 a 30 de junho de 1999, no auditório da Biblioteca do Museu Nacional, no Rio de Janeiro. Com mais de 150 participantes - um número elevado, considerando-se o caráter relativamente periférico do Rio de Janeiro em relação às rotas dos problemas indígenas no Brasil - ao longo de seus dias, contamos com figuras de grande relevo para a questão

12 O material gravado então - e ampliado em momentos posteriores - encontra-se digitalizado. Naquele período, ele serviu à edição de dois vídeos sobre a temática indígena, um produzido diretamente por projetos do Laced, cujo tema central é o "movimento indígena organizado" daquele período, intitulado Pisa ligeiro (2004), o outro produzido por mim para a Associação Brasileira de Antropologia, na gestão de Ruben Oliven, intitulado Muita terra para pouco índio? (2002), e abordando a situação fundiária dos povos indígenas naquele momento e os preconceitos existentes, dentre eles aqueles sobre os índios do Nordeste, ambos dirigidos por Bruno Pacheco de Oliveira.

13 Ver Souza Lima et al. (2004), Pacheco de Oliveira (2008) e Valente (2010), dentre outros. 
na época, dentre outros, como a então senadora Marina Silva; Marcio Santilli, do Instituto Socioambiental, que fora presidente da Fundação Nacional do Índio (Funai), por alguns meses, nos anos de 1995-1996; Gilberto Azanha (do Centro de Trabalho Indigenista - CTI); Ubiratan Pedrosa Moreira (da Fundação Nacional de Saúde - Funasa, o responsável pela implantação do subsistema de saúde indígena); Artur Nobre Mendes, responsável na Funai pelo PPTAL e depois seu presidente; Ruth Cardoso, na época, à frente do Programa Comunidade Solidária e Daniel Gross, do Banco Mundial. Estavam presentes também importantes lideranças indígenas como Gersem Luciano Baniwa, Siã Kaxinawá, Ailton Krenak, Megaron Kayapó, Wilson Pataxó, Francisca (Chikinha) Novantino Pareci e muitos outros, num formato de seminário que rompia com o usual na área da política indigenista e mesmo em seminários acadêmicos até aquele momento, nos quais os índios tinham suas mesas, os antropólogos as suas, os gestores públicos idem, etc. No nosso caso, cada mesa tinha componentes - indígenas ou não indígenas, acadêmicos, lideranças, gestores, etc. - adequados ao debate dos temas com os quais a havíamos organizado. Tal concepção nos pareceu ser uma forma de trabalharmos dentro da "lógica da participação", que se disseminava, tendo sido claramente reivindicada pelos indígenas desde o processo constituinte, aliada à nossa vontade de estabelecer de fato um diálogo e uma posição simétrica. A partir da pesquisa realizada, eu me ocupei de apresentar os argumentos iniciais para a discussão sobre problemas de formação de pessoal, indígena e não indígena, para as políticas indigenistas, o que redundaria em texto posteriormente publicado numa das três coletâneas resultantes do seminário. ${ }^{14}$

A esse projeto seguiram-se outros dois, nos quais, apesar de meu interesse em estudar cooperação técnica internacional e seu papel pedagógico na implantação de tecnologias de governança de cunho neoliberal, em sua peculiar fusão com os marcos de uma democracia participativa - o que acabou atraindo alunos, ensejando cursos na pós-graduação, e até alguma escrita - na formação de "novas elites", acabei por me ver a braços com outra direção muito mais prática de trabalhos, na qual se a pesquisa não estava ausente, estava

14 Para o meu texto, ver Souza Lima (2002). O seminário resultou num relatório em forma de texto e outro em forma de vídeo. Para o relatório, ver Seminário Bases para uma Nova Política Indigenista (1999); para o relatório em vídeo, ver Bases para uma nova Política Indigenista (2000). Três anos após, em 2002, Maria Macedo Barroso e eu publicamos três coletâneas geradas a partir das falas dos autores. Para as coletâneas, ver Souza Lima e Barroso-Hoffmann (2002a, 2002b, 2002c). 
subsumida a outras atividades, o que marcaria meu trabalho em anos posteriores. Assim, e em função do tipo do segundo financiamento que nos seria feito pela FF, organizamos, em janeiro de 2001, o Laboratório de Pesquisas em Etnicidade, Cultura e Desenvolvimento (Laced), um laboratório (o primeiro dos núcleos do PPGAS e um dos primeiros laboratórios formalizados como tais do próprio Museu Nacional, para quem esse termo tinha um outro sentido) que visava aglutinar e acolher uma ampla e frouxa rede de pesquisadores com variados níveis de formação, inserção institucional, e em temáticas igualmente amplas, mas que tinham em comum a preocupação de publicizar os resultados de pesquisas, em coligir material e organizá-lo analiticamente.

Nos projetos seguintes, minha parte (já distinta da de João Pacheco de Oliveira) esteve focada na criação e implementação de cursos de especialização para a formação de gestores em etnodesenvolvimento, realizados fora do Museu Nacional, um na Universidade Federal do Amazonas (Ufam), e outro na Universidade Federal de Roraima (UFRR), entre os anos de 2002 e 2003. Nessa experiência, o Laced/Museu Nacional já atuava como mediador de alguns recursos da Fundação Ford para essas universidades. No que diz respeito ao curso da Ufam ainda foi possível contar com recursos da Capes, sob o argumento da necessidade desse tipo de formação, em especial na região da Amazônia. ${ }^{15}$

Os cursos em si foram estruturados não apenas a partir do que julgávamos que deveriam conter, mas também das lógicas e possibilidades concretas das universidades em que se realizaram e que deles se reapropriaram de diferentes formas. Creio que serviram ainda de inspiração a outros processos formativos no nível de especialização, e mesmo de graduação, para a área de sustentabilidade, um tema que mais tarde exploraríamos. Nesses dois cursos, contou-se com o estímulo à presença de indígenas já graduados, quando possível através de bolsas, mas estávamos longe da ideia de cotas ou algo que se assemelhasse à discussão já em curso, puxada na esfera pública por setores do movimento negro e por uma ampla maioria de profissionais envolvidos com a área de educação, além de alguns antropólogos.

15 No site do Laced (http://www.laced.etc.br), há o estatuto do laboratório, aprovado pela Egrégia Congregação do Museu Nacional em janeiro de 2001. Sobre os cursos de especialização, ver http:// laced.etc.br/site/atividades/cursos/curso-gestao-em-etno/, para o da Ufam; e http://laced.etc.br/ site/atividades/cursos/curso-gestao-em-etnodes/, para o da UFRR (acessados em 07/09/2017). 
O perfil inicial desses cursos emergiu, pois, exatamente das discussões surgidas na pesquisa e no seminário Bases para uma Nova Política Indigenista e diante do amplo processo de transformação da vida social de muitos povos indígenas, que se aceleraria nos anos vindouros em face do reconhecimento (quando foi o caso) de seus territórios dentro de limites "fechados". Em larga medida, o que víamos - e os indígenas explicitamente reivindicavam - era a necessidade de formação de pessoal capacitado para lidar com as políticas que se desdobraram a partir dos direitos reconhecidos pela Constituição Federal de 1988, e que implicaram uma reestruturação não muito fluida da ação federal junto aos povos indígenas.

Afinal, as organizações indígenas viam-se a braços com a gestão de distritos sanitários indígenas e tantas outras funções para as quais não estavam preparadas. ${ }^{16}$ Ademais, diante das inúmeras iniciativas de "capacitação" (sobretudo gerencial, mas não só) promovidas por agências da cooperação técnica internacional para o desenvolvimento, assim como por redes de ONGs, entendiam que necessitavam de uma compreensão mais profunda sobre certas questões. Nesse momento, já se evidenciava também que esses inúmeros cursos não lhes conferiam títulos, o que em muitas regiões do país era importante, pois lhes facultaria o acesso profissional a instâncias da administração pública, primordialmente no nível municipal, mas também estadual e federal. Falava-se explicitamente em entrar para as universidades com o objetivo de obter conhecimentos de modo a prescindir da mediação de não indígenas. E, na verdade, constatamos que, àquela época, em muitos pontos do Brasil, havia indígenas que se graduaram com grandes dificuldades, mantendo-se por vezes com uma ajuda irregular mas fundamental da Funai, muitas vezes em universidades particulares. Outros tiveram êxito em acessar universidades públicas, mas nem sempre conseguiram nelas permanecer. Desde aquele momento registramos que o problema do acesso, ainda que não fosse menor, constituía apenas uma dimensão do que ainda precisaria ser enfrentado.

16 Algumas dessas organizações foram responsabilizadas por infrações fiscais e trabalhistas que acabaram por gerar uma responsabilização totalmente extemporânea diante de suas reais capacidades de operação, bem como das lógicas culturais dos povos que nelas se reuniam, e caíram assim num círculo vicioso que, em alguns casos, só agora parece encontrar horizontes de solução. Já estavam aí as raízes de um amplo processo de judicialização dos movimentos sociais que, como temos assistido, não cessa de crescer. 
Em 2001-2002 estavam dadas as condições de surgimento do Projeto Trilhas de conhecimentos. Se a demanda por acesso a cursos regulares se desenhava em função da presença cada dia mais intensa das políticas governamentais na vida indígena, inclusive pela reivindicação de participação política e execução em algumas delas, um outro lado da busca por formação superior (que tampouco deixa de ser um modo de inserção em políticas governamentais) se dava pela demanda de formação de professores, um item da política específica de "educação escolar indígena, intercultural, bilíngue e diferenciada". ${ }^{17}$ O Plano Nacional de Educação 2001-2010, aprovado pela lei $\mathrm{n}^{\circ} 10.172$, de 9 de janeiro de 2001, trata em seu capítulo 9 da educação indígena, estabelecendo em suas metas 15, 16, 17, 19 e 20 a formação de professores indígenas (Grupioni, 2003, p. 16-18). ${ }^{18}$ Os índices relativos à formação de professores de modo mais geral eram desastrosos, e o referido Plano colocava como meta fundamental a reversão desses indicadores. Ou seja, a formação de professores indígenas fazia parte de metas políticas mais globais, que se estenderiam do ano de 2001 em diante, e que estão presentes na formulação do PNE vigente para o período de 2014-2024. ${ }^{19}$

Em 1998-1999, uma comissão interinstitucional e paritária desenhou e redigiu o projeto do que veio a ser o curso de Licenciatura Intercultural Indígena da Universidade do Estado de Mato Grosso (Unemat), hoje Faculdade Intercultural Indígena. O curso teve seu início efetivo em 2001, após um ano de negociações políticas e financeiras. Para lá afluíram professores indígenas das mais variadas partes do Brasil, em busca de um curso marcado pela estrutura modular e pela formação em serviço. ${ }^{20} \mathrm{Em} 2006$ a primeira turma concluiu o ciclo da formação, e nela formaram-se 186 indígenas. A faculdade ministra

17 Há muita coisa escrita sobre a educação escolar indígena no Brasil, cuja constituição como articulação social, formulação de políticas e implementação remonta ao início dos anos 1990 e tem importância fundamental para se entender, inclusive no plano político, a ação governamental nos cenários indígenas no país. Ver, dentre muitos outros, Franchetto (2002), Matos (2002, 2013) e Guimarães (2013). Para a conexão entre a demanda por acesso a cursos universais e a por formação de professores, ver Barroso (2013). Para uma visão didática e introdutória da política de educação escolar indígena, ver Paladino e Almeida (2012).

18 Ver também, dentre outros, Silva, R. (2002).

19 O PNE 2014-2024 foi aprovado pela lei $\mathrm{n}^{\circ}$ 13.005, de 25 de junho de 2014 (Brasil, 2014b).

20 Para um breve histórico institucional desse pioneiro e importantíssimo esforço, ver Universidade do Estado de Mato Grosso (2016). 
atualmente o curso de Licenciatura Intercultural, uma Licenciatura em Pedagogia e, de 2002 a 2004, já ofereceu uma pós-graduação lato sensu em educação escolar indígena.

Em 2001, ainda, por resolução do Conselho Universitário da Universidade Federal de Roraima, criou-se o Núcleo Insikiran de Formação Superior Indígena, hoje um instituto que abarca três cursos, a Licenciatura Intercultural, criada em 2001, o Bacharelado em Gestão Territorial Indígena (criado em 2009) e o Bacharelado em Gestão de Saúde Coletiva Indígena (2012). ${ }^{21}$ A licenciatura começaria a funcionar efetivamente apenas em 2003.

Tanto o curso da Unemat quanto aquele da UFRR tiveram de enfrentar enormes dificuldades e contaram com um substancial apoio da Funai, o que não significa que tenham contado com um aporte significativo de verbas, que nunca existiram para essa área, como de resto para muitas questões referentes aos povos indígenas no Brasil. No entanto, a experiência de gestão com que a Funai lidava e os desafios em face dos quais teve de encontrar saídas na intrincada máquina pública brasileira conferiram-lhe uma capacidade operacional que outras agências da administração pública não detinham. Ademais, naquele momento, a Funai já financiava de modo esparso e com recursos muito variados, por meio dos fundos destinados à assistência aos indígenas, alunos indígenas em cursos de ensino superior numa demanda crescente a partir dos meados de 1990, tendo chegado a manter 34 casas de estudantes. $^{22}$

Porém, como fruto da reestruturação que paulatinamente se implantaria com os decretos presidenciais $n^{\circ} 23,24,25$ e 26 , de 4 de fevereiro de 1991, de Fernando Collor de Mello, as tarefas relativas respectivamente à saúde, ao meio ambiente em terras indígenas, ao desenvolvimento rural e à educação, exercidas com enorme precariedade - salvo exceções pontuais - pela Funai, foram atribuídas aos Ministérios da Saúde (MS), do Meio Ambiente (MMA), ao Ministério da Agricultura e da Reforma Agrária (hoje Ministério do Desenvolvimento

21 Para o site institucional do Instituto Insikiran, ver http://ufrr.br/insikiran/index. php?option=com_content\&view=category\&layout=blog\&id=18\&Itemid=102 (acessado em 07/09/2017).

22 Para a ação da Funai no tocante ao fundamental suporte à presença indígena no ensino superior, ver Cunha (2007), Fialho, Menezes e Ramos (2013) e Almeida, N. (2014). 
Agrário - MDA) e da Educação. ${ }^{23}$ Na prática, isso significou que o orçamento da Funai para questões de educação fosse aos poucos podado, e que tampouco o MEC assumisse imediatamente o fomento ao ensino superior de indígenas, em especial no referente ao suporte ao acesso diferenciado e à permanência nas universidades. ${ }^{24}$

Cabe aqui fazer menção a uma dimensão que sempre foi crucial na gestão pública das questões indígenas e uma clara manifestação de como supostas ideologias multiculturalistas (pluriétnicas, etc.) esbarram numa dimensão que tenho destacado, desde minha pesquisa para o doutorado (Souza Lima, 1995): seguindo Max Weber, a do papel da administração no exercício cotidiano das formas de dominação. ${ }^{25}$ É importante, portanto, ter em conta que os anos aqui em análise são caudatários dos efeitos da aplicação (ou de suas tentativas) da Constituição de 1988 que, se trouxeram mudanças no sentido de uma "democracia participativa" (no caso indígena muito reivindicada), também implicaram a implantação de certa accountability à brasileira, que só prosseguiria no sentido de uma responsabilização lida de forma crescente como culpabilização, de uma hipernormatização que só abriria mais e mais caminhos a práticas passíveis de serem lidas como corrupção, logo a produzir os mais variados atos ilícitos na vida pública. Agregue-se a isso que, nos anos dos governos de Fernando Henrique Cardoso, tentara-se levar a cabo uma reforma do Estado, que acabaria perigosamente pela metade, com efeitos bastante perversos para as "novas políticas indigenistas". 26

Os anos de 2001 e 2002 também foram importantes na medida em que ações em múltiplos planos durante a década de 1990 convergiram para medidas e debates que seguiram em pauta na primeira década do novo milênio. Assim, e para citar apenas algumas ações, em 1995, o governo de Fernando Henrique Cardoso criou o Grupo de Trabalho Interministerial para a Valorização

23 Ver Souza Lima (2010).

24 Para as ações do MEC nos primeiros anos de sua atuação, ver Bondim (2013), Matos (2013) e Guimarães (2013).

25 Ver Weber (1983, p. 175).

26 Ver Oliven, Ridenti e Brandão (2008) para análises sobre alguns dos mais importantes efeitos sociais da Constituição de 1988, em particular os textos de Vianna e Sadek. Sobre aspectos dessa responsabilização à brasileira, a referência fundamental é, sem dúvida, o extenso trabalho de Roberto Kant de Lima (cf. Kant de Lima, 2013, dentre outros). 
da População Negra, como parte do Programa Nacional de Direitos Humanos. A deputada Nilce Lobão (PFL/MA) elaborou o projeto de lei $n^{\circ} 73 / 1999$, que ficou conhecido como "Lei de Cotas", ao qual foram apensados diversos outros projetos de lei correlatos. Em 2000, o senador Paulo Paim (PT/RS) apresentou o projeto de lei $n^{\circ} 3.198$, que propôs instituir o Estatuto da Igualdade Racial. Na preparação para a III Conferência Mundial contra o Racismo, a Discriminação, a Xenofobia e a Intolerância Correlata, realizada em Durban, África do Sul, entre 31 de agosto e 8 de setembro de 2001, realizou-se no Rio de Janeiro a Conferência Nacional contra o Racismo e a Intolerância, que aprovou a "Carta do Rio" - Plano Nacional de Combate ao Racismo e à Intolerância, que estabelecia a necessidade de políticas de ação afirmativa em diversos níveis (Almeida, N., 2013, p. 163-165). Fernando Henrique Cardoso mencionou publicamente, no final do ano de 2002, a permanência do racismo no Brasil. Por fim, e para mencionar apenas alguns elementos, as leis estaduais $n^{\circ} 3.524 / 2000$ e $\mathrm{n}^{\circ} 3.708 / 2001$ (posteriormente revogadas e substituídas pela lei $\mathrm{n}^{\circ} 4.151 / 2003$ ) estabeleceram pioneiramente para as universidades do estado do Rio de Janeiro (Universidade do Estado do Rio de Janeiro - Uerj e Universidade do Norte Fluminense - Uenf) a política de cotas. ${ }^{27}$

Assim, criou-se em 2002 o Programa Diversidade na Universidade, voltado para o financiamento de cursos pré-vestibulares para negros, com recursos do Banco Interamericano de Desenvolvimento, sediado no Ministério da Educação. ${ }^{28}$ Os recursos do programa seriam posteriormente reorientados à criação da Secretaria de Educação Continuada, Alfabetização e Diversidade (Secad), pelo decreto $\mathrm{n}^{\circ} 5.159$, de 28 de julho de 2004 , que teria à sua frente o economista português naturalizado brasileiro Ricardo Henriques. ${ }^{29}$ Henriques,

27 Para o documento final da Conferência de Durban, ver Informe... (2001). Para declarações de Fernando Henrique Cardoso, ver Ainda... (2002). Para o estabelecimento de cotas nas universidades do Rio de Janeiro, ver Peria (2004) e Brandão (2007).

28 Sobre a criação do Programa Diversidade na Universidade, ver Brasil (2002). Ainda sobre o Programa Diversidade na Universidade, ver Almeida, N. (2008; 2013) e Braga e Silveira (2007), dentre outros.

29 No canal do Instituto Unibanco no YouTube, apresenta-se uma entrevista com esse ator (https:// www.youtube.com/watch?v=Vm94g6uGeMM - acessado em 07/09/2017), cuja trajetória é em si matéria para reflexão sociológica sobre múltiplas questões no terreno movediço entre academia, gestão pública e agora "filantropia privada brasileira". A entrevista é introduzida por um texto elucidativo sobre sua trajetória. 
hoje superintendente executivo do Instituto Unibanco, e ainda professor do Departamento de Economia da Universidade Federal Fluminense, à época era também pesquisador do Instituto de Pesquisa Econômica Aplicada (Ipea), tendo publicado um trabalho que foi essencial para o debate público daquele momento, intitulado "Desigualdade racial no Brasil: evolução das condições de vida na década de 90" (Henriques, 2001). A Secad, que em 2011 ganharia o "i" de inclusão, passando a se chamar Secadi, estava encarregada da ação transversal no MEC, no tocante a toda pauta da inclusão e da diversidade, lidando com questões tão diferentes quanto complexas, como alfabetização, educação de jovens e adultos, educação escolar indígena, educação do campo, educação para diversidade étnico racial, educação para comunidades remanescentes de quilombos, educação para crianças em situação de discriminação e vulnerabilidade social, às quais ainda seria acrescida a temática de gênero e sexualidade.

A partir de 2001, com o caso das universidades estaduais do Paraná (a partir de 2005, também com a participação da Universidade Federal do Paraná - UFPR), e em 2003, com o da Universidade Estadual de Mato Grosso do Sul (Uems), começaram a ser realizados vestibulares para indígenas seja para cotas ou reservas de vagas, de acordo com o estabelecido em leis estaduais e que se tornariam processos seletivos diferenciados. ${ }^{30}$ Dessa maneira, a Funai foi o suporte fundamental não apenas dos cursos de licenciatura intercultural, mas também de muitos dos "vestibulares diferenciados", para tanto, tendo estabelecido acordos de cooperação com diversas universidades, assim como para o fomento da permanência de indígenas aprovados. Muitos outros convênios foram firmados e vigem ainda hoje. ${ }^{31}$

30 Para a ação da Funai no tocante à educação superior de indígenas, ver Cunha (2007), Fialho, Menezes e Ramos (2013) e Almeida, N. (2014). Para o vestibular indígena do Paraná, ver Paulino (2008, 2013, 2016), Amaral (2010) e Amaral, Fraga e Rodrigues (2016). Para a entrada da UFPR nas questões de ações afirmativas, numa preciosa reflexão a partir da antropologia, ver Bevilaqua (2005). Para o cotidiano da presença indígena no ensino no Paraná, ver Goulart (2014). Para a implantação de ações afirmativas na Uems, ver Cordeiro $(2007,2013)$. Para o site do vestibular da Uems, ver http://www.vestibular.uem.br/indigena/ (acessado em 07/09/2017); e para notícias recentes, ver Vestibular... (2017).

31 Ver Almeida, N. (2014, p. 165-184, 185 ss) para um quadro detalhado desse suporte. 
De meu ponto de vista, esse panorama geral não pode ser entendido sem a consideração das estratégias de financiamento da Fundação Ford no Brasil, seja no suporte à pesquisa em universidades ou organizações não governamentais, seja a organizações mais voltadas para a intervenção. No volume comemorativo dos 40 anos da FF no Brasil, organizado por Nigel Brooke e Mary Witoshynsky (2002), encontramos farta informação, e há muitos estudos sobre a ação da FF (assim como de outras fundações filantrópicas, como a Fundação Rockefeller, dentre muitas outras) para períodos anteriores. ${ }^{32}$ Se parcerias - para usar um termo que recobre relações muito complexas e sem equações simplistas - da FF com núcleos universitários, associações científicas e grandes fundações e organizações não governamentais são relativamente bem conhecidas, há muito mais para ser pensado, a ser dito e conhecido a partir dos anos 1990 e, em especial, quando se trata de um conhecimento que deve ser construído a partir de uma miríade dispersa de organizações e grupos de pesquisa. ${ }^{33}$ Maria Malta Campos (2002, p. 117) destaca a mudança que Nigel Brooke imprimiu ao longo dos anos 1990, com uma virada da área da educação superior para a da "reforma educacional", sendo que uma de suas direções, dando prosseguimento

32 Nigel Pelham de Leighton Brooke é inglês, graduado em Psicologia Experimental (1969 - University of Reading), Mestre em Psicologia Ocupacional (1973 - University of London) e doutor em Estudos do Desenvolvimento (1979 - Institute of Development Studies). Atuou como assessor de Programas de Educação no escritório da Fundação Ford no Brasil de 1994 a 1996 e também se tornou representante da fundação no período entre 1996 e 2003. É pesquisador associado da Faculdade de Educação da Universidade Federal de Minas Gerais (UFMG), cuja importância em matéria de ação afirmativa merece ser cuidadosamente analisada. Ver http:// lattes.cnpq.br/4918354189061801 e http://www.fae.ufmg.br/pagina.php?page=game (acessado em 07/09/2017).

33 Sobre a atuação da FF no Brasil, ver, dentre outros, Miceli (1993, 1995), Canêdo (2009, 2014), Canedo e Garcia Jr. (2011), Faria e Costa (2006) e Rocha (2016/2017). Para a ação da FF e de outras fundações no campo da educação superior na África, ver Jaumont (2014). Para os temas que se entrecruzam no tocante às ações afirmativas para os povos indígenas foram de grande importância os trabalhos do próprio Nigel Brooke, à frente do Programa de Educação e depois também do escritório no Brasil, de Anthony Anderson (1990-1996) e, depois de José Gabriel Lopez (19972003) e Aurélio Vianna (2004-) à frente do Programa de Meio Ambiente e Desenvolvimento, hoje redefinido; Edward Telles (1997-2000) e Denise Dora (2000-2011), no Programa de Direitos Humanos; de Ondina Fachel Leal (2000-2006), no Programa de Sexualidade e Saúde Reprodutiva. Ao longo de mais de 30 anos de contato com a fundação, vi grandes transformações tanto no nível nacional quanto internacional, com mudanças gerenciais, de dinâmica de funcionamento operacional e construção de quadros analíticos bastante distintos. Assim, num dado momento, a temática educacional, por exemplo, integrou áreas que nos pareceriam muito distintas. 
a tendências anteriores, mas com mais ênfase, foi a do "combate às desigualdades raciais na educação".

No ano de 2001, a FF criou uma fundação independente para gerir um amplo programa com duração prevista para uma década e abrangência mundial, voltado para dar suporte aos estudos pós-graduados de "líderes da mudança social das populações mais vulneráveis do mundo", denominado International Fellowship Program (IFP), com doação inicial de US\$ 280 milhões. Sua direção foi entregue a Joan Dassin, anteriormente representante da Fundação Ford no Brasil, de 1989 a 1992. Em 2013, foram 4300 bolsistas que se pós-graduaram e desenvolveram estudos pós-doutorais. ${ }^{34}$ O IFP foi implementado no Brasil a partir da Fundação Carlos Chagas como Programa Internacional de Bolsas e coordenado por Fulvia (de Barros Mott) Rosemberg. ${ }^{35}$

A primeira constatação, logo no início do IFP em nível global, foi a de que muitas categorias populacionais "menos favorecidas", "sub-representadas" ou "vulneráveis", que não acessavam a pós-graduação em diferentes países, não chegavam a ela porque não chegavam sequer à graduação. Isso acabou por suscitar a criação de uma "iniciativa", a Pathways to Higher Education Initiative (PHEI), em 2001, com uma dotação de US\$ 50 milhões, para que essas categorias acessassem e permanecessem na graduação. A PHEI foi inicialmente dirigida por Janice Petrovich, até sua saída da Fundação Ford, em maio de 2008. A PHEI voltou sua atenção para o que seus formuladores percebiam como o nível a ser transformado para que houvesse a efetiva entrada na graduação das populações "sub-representadas" nas quais se queria focar. Ao contrário do IFP, porém, os recursos da PHEI não podiam ser utilizados para pagar bolsas de manutenção aos estudantes indígenas, o que foi sempre seu maior limite e inadequação, ao menos à situação brasileira, traindo o que o seu viés constituinte supunha como uma autonomia universitária baseada em recursos financeiros próprios, muito diferente da realidade com que lidamos.

34 Para a página atual do IFP, ver https://www.fordfoundation.org/work/learning/international-fellowships-program/ (acessado em 07/09/2017).

35 Fulvia Rosemberg lamentavelmente faleceu em 2014, uma das perdas muito sentidas que tivemos ao longo dos anos de investimento na formação superior de indígenas. Sobre Fulvia, ver Campos et al. (2014). Para uma de suas análises sobre o programa no Brasil, ver Rosemberg (2013). Para a relação entre o Programa Bolsa/FCC e o PTC, ver Rosemberg e Andrade (2013). 
Em outubro de 2002, José Gabriel Lopez, o PO de Meio Ambiente e Desenvolvimento (e não de educação), propôs a João Pacheco de Oliveira e a mim que elaborássemos um ensaio propositivo (concept paper) para um programa voltado para o fomento à educação superior, a ser submetido na FF à "iniciativa" Pathways, abarcando não apenas indígenas, mas também seringueiros e ribeirinhos. Ele o redefiniu em alguns pontos e o apresentou com sucesso à direção da Fundação Ford em Nova Iorque, em novembro de 2002. O valor aprovado pela PHEI para um período inicial de três anos foi o de US\$ 1,2 milhão, destinados ao escritório da Ford no Brasil para que desenvolvesse o referido projeto.

Aurélio Vianna Jr. (2015, p. vii) apresenta uma síntese retrospectiva sobre as razões desse desenho, do ponto de vista do seu papel como PO, sendo que posteriormente (em 2004) assumiria a área de meio ambiente e desenvolvimento do escritório da Ford no Brasil e também a responsabilidade sobre o que, para a $\mathrm{FF}$, sempre fora o "Pathways indígena" do Brasil:

Em 2001, o escritório do Brasil começou a discutir a iniciativa global Pathways, e Brooke foi responsável por uma doação ao Laboratório Políticas da Cor [sic], da Universidade Estadual do Rio de Janeiro, de apoio ao acesso à educação superior para afro-brasileiros.

A seguir, verificou-se a possibilidade de apoiar a formulação de um programa de educação superior para a formação de "populações tradicionais". O sucesso do Laboratório de Pesquisas em Etnicidade, Cultura e Desenvolvimento (LACED) do Museu Nacional (MN) da Universidade Federal do Rio de Janeiro (UFRJ), com o Curso de Especialização Gestão em Etnodesenvolvimento, organizado em 2002, em parceria com a Universidade Federal do Amazonas (UFAM) e apoiado pela Fundação Ford, qualificava-o para coordenar a iniciativa e serviu como parâmetro para o diálogo sobre uma nova proposta na área de educação a ser apoiada pela Fundação Ford.

Ao escolher o LACED como donatário, a Fundação garantia que esse programa de educação estaria vinculado, ao mesmo tempo, ao debate mais amplo sobre povos indígenas e políticas públicas e, por outro, às organizações indígenas que participavam dos movimentos indígenas. Ou seja, o que parece ter sido decisivo na escolha não foi o acúmulo do LACED no campo da educação superior - onde existiam outras instituições acadêmicas com bem mais acúmulo e legitimidade, mas sua experiência e reconhecimento como um centro de excelência em 
relação à questão indígena e políticas públicas, particularmente as relativas a territorialidades. ${ }^{36}$

No início de 2003 sabíamos pouco (ou nada) dos contornos e orientações da PHEI. Só conseguiríamos recompor os impasses e as decisões acontecidas em esferas que nos eram alheias e que levaram a uma série de mudanças, ao longo dos anos de trabalho. O fato é que, logo no início de 2003, o foco do projeto foi redefinido de "populações tradicionais" (como era a intenção de José Gabriel Lopez, em 2002) para apenas "povos indígenas".

O primeiro desenho de um projeto efetivo de trabalho foi pensado à luz de dados da realidade indígena e educacional brasileira, com destaque para o caráter minoritário e reduzido em termos numéricos da população indígena no Brasil, para sua grande diversidade sociocultural e linguística e para o fato de que os povos indígenas têm direitos sobre uma porção significativa do território brasileiro, em particular na região amazônica. Havia ainda um dado que tornava a situação indígena em tudo distinta de outras na América Latina, onde já estavam sendo implementados programas a partir de recursos e princípios da PHEI: apesar da demanda existente, pouca ou nenhuma preocupação traduzida em pautas de reivindicação e ação por parte do "movimento indígena organizado" pelo acesso ao ensino superior, com relativa exceção feita às organizações de professores indígenas e à demanda ainda muito abstrata pela criação de licenciaturas interculturais. O projeto assim desenhado não

36 Sobre o Programa Políticas da Cor na Educação Brasileira, vinculado ao Laboratório de Políticas Públicas da UERJ, de extrema importância no tocante às ações afirmativas para negros e levado a cabo de 2001 a 2011, no currículo Lattes de Pablo Antonio Amadeo Gentili, seu coordenador, encontramos uma breve descrição que dá a noção do seu ponto de partida: "A primeira iniciativa do Programa Políticas da Cor na Educação Brasileira foi o Concurso Nacional Cor no Ensino Superior, desenvolvido em parceria com a Fundação Ford. O concurso destinou-se à seleção e financiamento de propostas e projetos orientados a promover ações, programas e iniciativas que visem ampliar as condições de acesso e/ou permanência de membros dos grupos historicamente excluídos das instituições de ensino superior brasileiro, especialmente os afro-brasileiros carentes. Entende-se por ampliar as condições de 'acesso': projetos que visem aumentar a probabilidade de ingresso no ensino superior. E, por 'permanência': projetos que promovam o aumento da probabilidade de completar o curso universitário, tais como aqueles que estimulam o envolvimento." O projeto desenvolveu uma intensa atividade tanto através das universidades que financiou quanto por meio do fomento do debate público e da produção de conhecimento científico em torno do tema das ações afirmativas para negros, essencialmente. Ver CV: http:// lattes.cnpq.br/7571532793457829 (acessado em 07/09/2017). 
pretendia atingir meramente indivíduos, ainda que também considerasse os indígenas residentes em centros urbanos, mas pensava nesse e em todos os casos numa necessária conexão com as variadas formas de ação coletiva dos povos indígenas.

No tocante ao sistema universitário, destacávamos o fato de que, no Brasil, as universidades federais públicas ocupavam o epicentro do sistema em matéria de inovação e qualidade. Se essas universidades eram/são dotadas de uma autonomia (apenas) relativa, o governo federal mantém diante das mesmas um papel de singular importância na promoção de temáticas, ações, em suma, de fomento e balizamento. Assim, parecia-nos que, independentemente da implantação de núcleos e da criação de mecanismos de acesso com recursos como os da Fundação Ford, poderiam cair num mar de problemas e nunca conseguir o efeito demonstrativo e de transformação que os propositores da PHEI - de início bastante focados em sistemas muito distintos do brasileiro almejavam alcançar. Anos depois tanto a implantação do Programa de Apoio a Planos de Reestruturação e Expansão das Universidades Federais (Reuni), instituído pelo decreto $\mathrm{n}^{\circ} 6.096$, de 24 de abril de 2007, quanto a lei $\mathrm{n}^{\circ} 12.711$, de 29 de agosto de 2012, a "Lei de Cotas", como ficou conhecida, viriam a demonstrar que nossa percepção estava correta, e que sem algum aporte do governo federal, independentemente de iniciativas importantes de universidade estaduais e da criação de núcleos universitários voltados para as ações afirmativas, como propugnava a PHEI, não haveria o efeito multiplicador que se esperava atingir, visando mudar um sistema a partir de alterações em instituições específicas.

De acordo com essa perspectiva, o primeiro desenho do projeto estava pensado para articular universidades e organizações indígenas em contextos regionais específicos, de modo a que, juntas, demandassem políticas governamentais no nível federal e estadual que viabilizassem o suporte material necessário ao ensino superior de indígenas com todas as implicações que antevíamos. Para isso desenhamos como ponto de partida um ciclo intenso de seminários de articulação política visando promover o estabelecimento de um movimento em rede. A ele sucederia a criação de cinco núcleos universitários com cursos preparatórios ao acesso à universidade. Tínhamos em mente que a Unemat e a UFRR deveriam ser contempladas, até porque em ambos os casos a articulação política entre universidades e organizações indígenas já estava em 
curso. Esse desenho já estava fechado e com orçamento estabelecido quando, em junho de 2003, José Gabriel Lopez deixou a FF, uma vez findo o seu contrato. Após sua saída, e com a explicitação de aspectos da PHEI que desconhecíamos, tivemos de reelaborar integralmente o projeto, o que se deu sob a responsabilidade de Ondina Fachel Leal, do Programa de Sexualidade e Saúde Reprodutiva e, em última instância, de Ana Toni, que sucedeu Nigel Brooke no cargo de representante da FF no Brasil, em 2003.37

Vimos, assim, um projeto voltado para a formação de novas lideranças, com o objetivo maior de contribuir para a ação coletiva dos povos indígenas, ser limitado à tarefa de "propiciar a mudança das instituições universitárias" a fim de promover transformações sociais mais amplas via capacitação de indivíduos, o que, no que concerne à formação de indígenas poderia se tornar mais um problema do que uma proposta de solução. Ao longo do segundo semestre de 2003, João Pacheco de Oliveira desligou-se do projeto, por essas e outras razões, tendo sido Maria Macedo Barroso e eu a levarmos adiante tanto o processo de negociação e enquadramento do projeto quanto o início da realização de sua primeira etapa. ${ }^{38}$

37 Segundo Vianna Jr. (2015, p. vi): “O programa Pathways apoiou uma notável diversidade de ações em onze países, sendo que, entre eles, apenas no Brasil considerou-se apoiar projetos que delimitassem seus 'beneficiários' de diferentes maneiras. Assim, a Fundação apoiou projetos em dois grandes campos: 'afro-brasileiros' ('estudantes negros e pardos') e 'indígenas', e, em um único caso, estudantes classificados como 'povos tradicionais'. E, à exceção da primeira doação feita em 2001, todas as outras tiveram como responsáveis oficiais de programas da Fundação Ford que não eram da área de Educação, mas de Direitos Humanos, Saúde Reprodutiva e Sexualidade, Desenvolvimento Sustentável e Meio Ambiente e Desenvolvimento. Gabriel Lopez, oficial do Programa de Desenvolvimento Sustentável, foi responsável pela primeira doação ao Pathways 'indígena'. Ondina Leal, de Sexualidade e Saúde Reprodutiva, deu seguimento à mesma doação; Denise Dora, de Direitos Humanos, foi a responsável pelas doações relativas a afrodescendentes; e, enfim, eu mesmo fui responsável pela segunda etapa do Pathways indígena e pela primeira doação a povos tradicionais, o já referido PAPIT [Programa de Políticas Afirmativas para Povos Indígenas e Populações Tradicionais, da Universidade Federal do Pará - ACS1]." Cabe, no entanto, a menção de que Janice Petrovich, a responsável pela implantação de Pathways, era, no plano da ação internacional da Ford, diretora de Educação, Conhecimento e Religião, dirigindo ações nos campos da educação (básica e superior), da sexualidade e saúde reprodutiva, e de religião, sociedade e cultura. O funcionamento e a política externa, bem como a política interna a cada escritório da Fundação Ford seriam matéria para uma pesquisa em si. Mais adiante, neste texto, mencionarei a relação com a Universidade Federal do Pará.

38 Maria Macedo Barroso afastou-se já no final de 2006, no meio da primeira etapa do PTC, para realizar a pesquisa de sua tese de doutorado na Noruega, contemplada pela Capes com o prêmio 
Ao mesmo tempo em que desenhávamos e redesenhávamos o projeto, estávamos em articulação com outros setores envolvidos na discussão sobre as possibilidades de ampliação do acesso de indígenas ao ensino superior. A discussão estava em larga medida restrita à criação de cursos de licenciatura intercultural para a formação em serviço de professores indígenas. Foi, portanto, a partir da entrada do governo Lula, ainda com Cristóvão Buarque à frente do Ministério da Educação (01/2003-01/2004), que se compôs um grupo de trabalho na Secretaria de Educação Superior (Sesu), na tentativa de estruturar mais amplamente as ações do governo para a educação escolar indígena, por meio da formação de professores indígenas. O grupo, do qual participei, contou com ampla participação de organizações indígenas, de ONGs, da Funai e de universidades, mas não gerou qualquer produto e foi apenas com a entrada de Tarso Genro na gestão da pasta da Educação (01/2004-07/2005) que de fato houve um encaminhamento mais orgânico e preciso quanto às questões relativas à educação escolar indígena em geral.

Se me estendi nas condições prévias, no preparo e na redefinição do projeto foi porque já ali nos víamos diante de uma das dimensões do nosso trabalho nos anos seguintes, que não deixou de ser uma fonte de estímulo à reflexão também sobre essa forma de cooperação técnica internacional que é a filantropia. Refiro-me ao funcionamento internacional de uma instituição filantrópica como a Fundação Ford, dimensão menos visível e menos demandante, quando estávamos num patamar de doações de menor monta e sem um conjunto de obrigações relativas à inserção em uma iniciativa de cunho internacional. Ainda em 2003, percebemos que, no âmbito da FF, o exemplo do "Pathways mexicano" - que enfocava indígenas e havia sido iniciado em março

de melhor tese do ano de antropologia em 2008 e posteriormente publicada (Barroso-Hoffmann, 2009). Trata-se de um primoroso estudo sobre cooperação internacional e ideologias filantrópicas, formação de Estado e antropologia, ativismo internacional e povos indígenas a partir da Noruega. É importante registar que esse país é uma das grandes fontes de recursos, por intermédio da Rain Forest Foundation, para projetos voltados para a educação de indígenas, desenvolvidos por organizações indigenistas e indígenas, muitas das quais hoje reunidas na chamada Rede de Cooperação (Amazônica [ex-Alternativa]). Aos sami, população nativa do norte da Escandinávia, e participantes da movimentação internacional para reconhecimento dos direitos dos povos indígenas na Organização das Nações Unidas, desde os anos 1970/80, havia sido entregue o direcionamento das ações de cooperação técnica internacional norueguesas no tocante a povos indígenas mundo afora. Ver http://rca.org.br/e http://www.institutoiepe. org.br/rede-de-cooperacao-alternativa-rca-brasil/ (acessados em 07/09/2017). 
de 2001, tendo sido pensado para um contexto indígena em tudo distinto do brasileiro - pesava como uma espécie de modelo a ser seguido, contrariamente ao desenho de atividades que propúnhamos. Chegaram mesmo a pensar em colocar a gestão do projeto na Associação Nacional de Dirigentes de Instituições Federais de Ensino Superior (Andifes) - que não tinha nem estrutura para administrá-lo nem tampouco evidenciava, naquele momento, qualquer interesse ou posicionamento positivo quanto a ações afirmativas. Só com o passar do tempo e em função de uma iniciativa conduzida por Maria Helena Gonzalez Plitt, coordenadora do Projeto Rüpu - Programa de Apoyo Académico para Estudiantes Mapuche, consegui estabelecer contato com alguns dos coordenadores desses outros programas na América Latina e entender as profundas diferenças de perspectivas e implicações diferenciais de ações só formalmente semelhantes. ${ }^{39}$

\section{O Projeto Trilhas de Conhecimentos - desafios, ações, obstáculos, desdobramentos}

Em fevereiro de 2004 o PTC finalmente inaugurou suas atividades, tendo como objetivos principais de sua primeira etapa (2004-2007): 1) fomentar iniciativas de ação afirmativa, de caráter demonstrativo e modelar, desenvolvidas por universidades, destinadas a dar suporte ao etnodesenvolvimento dos povos indígenas no Brasil, através da formação de indígenas em nível universitário;

39 Refiro-me à minha participação no Primero Encuentro Internacional de Estudiantes Pathways, na Universidad de la Frontera, em Temuco, no Chile, de 02 a 05/11/2005, quando os coordenadores de programas Pathways da América Latina e estudantes indígenas se reuniram e puderam trocar experiências. Soube então de um encontro anterior (e único) realizado em 2003 no México, entre todos os programas estabelecidos pela PHEI em diversos países. A PHEI, ao contrário de outras iniciativas globais da Ford desenvolvidas naquele período, não contava com uma "política de comunicação" adequada, nem fomentava a troca de experiências entre projetos apoiados de modo sistemático. Tampouco foi desenvolvido um trabalho de sistematização dos resultados dos projetos desenvolvidos no plano mundial. Sobre o "Pathways mexicano", ver Castillo Salazar (2012). Com uma perspectiva bem menos ambiciosa, logramos reunir, em agosto de 2007, junto com o Programa Rede de Saberes - um dos núcleos implantados (ver adiante) a partir de nossa ação - os coordenadores de alguns desses programas desenvolvidos com povos indígenas na América Latina num seminário realizado em Campo Grande, no Mato Grosso do Sul. Sobre o Projeto Rüpu, ver González Plitt e González Gómez (2012), e a página ainda existente em https://www2.ufro.cl/rupu/ (acessado em 07/09/2017). 
2) fomentar a capacitação de profissionais universitários para lidar com estudantes indígenas no nível universitário, que se propusessem a intervir em suas instituições, para transformá-las, no sentido da democratização do acesso e da permanência em seus cursos de indivíduos integrantes de povos indígenas, fazendo-o em diálogo com suas coletividades e variadas formas de articulação; 3) acompanhar e influenciar as políticas governamentais do ensino superior, nos planos federal e estadual, principalmente, de modo a que as experiências universitárias desenvolvidas nos quadros do projeto adquirissem sustentabilidade e replicabilidade.

Para tanto coube ao Laced a quantia de US\$ 346 mil por um período de três anos durante os quais deveríamos estruturar uma equipe e desenvolver um conjunto de ações. ${ }^{40}$ Nossa primeira tarefa foi indiscutivelmente gerencial, e esta não foi uma dimensão menor de todo o trabalho desenvolvido. Com isso refiro-me a toda uma atividade que implicaria permanentes negociações para ser viabilizada, uma demonstração da extrema precariedade e da falta de

40 A equipe foi inicialmente composta por Maria Macedo Barroso, hoje professora adjunta do Programa de Pós-Graduação em Sociologia e Antropologia do Instituto de Filosofia e Ciências Sociais da UFRJ; Sidnei Clemente Peres, ex-integrante do Peti, mestre pelo PPGAS/Museu Nacional e doutor em Ciências Sociais pela Universidade Estadual de Campinas (Unicamp), hoje professor titular de Sociologia da Universidade Federal Fluminense (UFF), que se desligaria já no início de 2005; Hellen Cristina de Souza, pedagoga, e mestre em Educação à época, professora da Unemat do campus de Tangará da Serra, que realizara até então o trabalho mais completo sobre a temática do ensino superior de indígenas no Brasil (Souza, 2003) para o Instituto Internacional para a Educação Internacional para a Educação Superior na América Latina e no Caribe (Iesalc), da Organização das Nações Unidas para Educação Ciência e Cultura, que deixaria o PTC ainda no segundo semestre de 2004; os estagiários de graduação (naquele momento) Priscilla Xavier, Vinicius Mesquita Rosenthal (que continuaram na vida acadêmica com outros temas e em outras instituições), Filipe Simões Corrêa Alves e Rodrigo Cipoli Cajueiro (que deixariam a área). A eles somava-se a atuação providencial na solução de diversas questões, das mais variadas atividades do projeto, do secretário Francisco Chagas Sousa, bacharel em Ciências Sociais pela UFF e hoje professor no Ciep Alceu Amoroso Lima, no qual já exerceu o cargo de diretor, em Duque de Caxias (RJ), cuja atuação logística foi sempre essencial para o funcionamento do projeto; e após uma primeira tentativa baldada, algumas atividades gerenciais foram assumidas também por Afonso Santoro, funcionário de carreira da UFRJ, administrador de projetos do PPGAS/Museu Nacional. A variação das equipes, com o trabalho sendo muitas vezes uma solução de compromisso entre investigações de mestrado e doutorado, foi talvez um dos itens mais difíceis de se lidar, sendo um limitador ponderável de esforços de pesquisa e de intervenção sediados em universidades federais. Na segunda etapa do PTC, João Paulo Macedo e Castro, hoje professor de Antropologia da Universidade Federal do Estado do Rio de Janeiro (Unirio), Marcos Moreira Paulino e, nos seus desdobramentos, Bruno Pacheco de Oliveira e Luis Felipe Carvalho foram fundamentais nos trabalhos que desenvolvemos. 
recursos institucionais com que alguns esforços de pesquisa e intervenção a partir da universidade são muitas vezes desenvolvidos. Tratava-se de transformar a sala do Peti em uma sala de trabalho para a equipe do PTC, reequipando-a, e tendo até mesmo que pagar uma linha telefônica com internet, pois o Museu Nacional, e através dele a UFRJ, não nos disponibilizou esses recursos. Ao mesmo tempo, por uma exigência do escritório da Fundação Ford no Rio de Janeiro, compusemos um comitê assessor que deveria dirimir qualquer dúvida que surgisse na relação entre o Laced e as universidades a serem financiadas, de modo a criar - essa era a intenção precípua - um "espaço de segurança" para a fundação, na hipótese de qualquer contestação legal no processo de seleção daqueles que seriam financiados. ${ }^{41}$ Conseguimos, no entanto, ampliar e transformar a função de mediação de possíveis conflitos desse comitê para a de aconselhamento e debate das propostas e ações do projeto. Por uma questão de objetividade textual, seguirei menos uma descrição cronológica e, daqui por diante, procurarei descrever os pontos fundamentais de nosso trabalho e ponderar alguns problemas principais que enfrentamos, o que

41 O comitê assessor foi composto por Fulvia (de Barros Mott) Rosemberg, mencionada acima, em função do necessário diálogo entre o PTC e o Programa Bolsa/FCC-FF; Maria Conceição Pinto de Góes, historiadora e ex-pró-reitora de Graduação da UFRJ, representando a reitoria de nossa universidade; Beatriz Maria Alasia de Heredia, antropóloga e professora do Instituto de Ciências Sociais da UFRJ, que desenvolvera uma consultoria para o escritório da FF no Rio de Janeiro, tendo sido essencial para o adequado entendimento das questões envolvidas num projeto de ação afirmativa para povos indígenas, no hiato entre a saída de José Gabriel Lopez e a entrada de Aurélio Vianna Jr.; Carlos (Everaldo Alvares) Coimbra Jr., antropólogo biológico e pesquisador titular da Fundação Oswaldo Cruz (Fiocruz), com extenso trabalho com os povos indígenas no Brasil; Nietta Lindberg Monte, antropóloga da Comissão Pró-Índio do Acre, especializada em educação escolar indígena e que já fizera uma avaliação do curso da Unemat; Gersem (José dos Santos) Luciano Baniwa, importante liderança indígena da região do Alto Rio Negro, na época mestrando em Antropologia da Universidade de Brasília (UnB) e bolsista do Programa Bolsa/ FCC-FF, ex-gerente indígena da carteira de projetos intitulada Projeto Demonstrativo de Povos Indígenas (http://www.mma.gov.br/apoio-a-projetos/povos-ind\%C3\%ADgenas - acessado em 07/09/2017); Etelvina Santana da Silva-Maninha Xukuru Kariri, destacada liderança indígena da Região Nordeste (estado de Alagoas), primeira mulher a integrar a Articulação dos Povos Indígenas do Nordeste, Minas e Espírito Santos (Apoinme), estudante de Filosofia naquele momento. As reuniões do comitê contaram sempre com a participação de Ondina Fachel Leal (2004) e Aurélio Vianna Jr. (de 2005 em diante), como POs da FF responsáveis pelo acompanhamento do projeto. Maninha Xukuru, cuja contribuição para o PTC foi inestimável, faleceu em Palmeiras dos Índios (AL), em 2006, em função da dificuldade em obter socorro para uma crise de asma. Para suas biografias, ver http://www.mulher500.org.br/acervo/biografia-detalhes. asp?cod=883 e http://laced.etc.br/site/acervo/videobiografias-indigenas/maninha-xucuru-kariri/ (acessados em 07/09/2017). 
foi possível aprender ao longo da experiência e reelaborar no processo de realização do PTC.

Os três grandes objetivos do projeto desdobraram-se em cinco blocos de ações desmembrados a partir da ação central à primeira etapa do PTC, isto é, a coordenação de um processo de indução da demanda por financiamento para a criação de núcleos destinados ao suporte à presença indígena em cursos de ensino superior, por parte de docentes universitários de algum modo articulados aos povos indígenas. Uma vez formuladas dentro dos marcos definidos no texto original do Trilhas e formalmente enviadas à equipe do Laced, essas propostas foram submetidas para nossa avaliação em conjunto com o comitê assessor e, quando aprovadas, foram financiadas. ${ }^{42}$

Ainda em 2003, fizemos os primeiros contatos com o Núcleo Insikiran (ainda em estruturação) da Universidade Federal de Roraima, antes mesmo de finalizada a reelaboração do projeto, e, uma vez que havia sido cortado o financiamento para a realização de grandes seminários de articulação e debate, fizemos uma solicitação de recursos a um edital do Fundo de Inclusão Social/ Banco Interamericano de Desenvolvimento (BID), visando à realização de um seminário nacional sobre o ensino superior de indígenas. ${ }^{43}$ Tivemos uma resposta positiva nos primeiros meses de 2004 e aí experimentamos o quanto a gestão de recursos pode ser exaustiva. Formalmente tratava-se de um projeto de cooperação técnica internacional, o que significava que deveria passar por todos os trâmites da Agência Brasileira de Cooperação (ABC) que, no Ministério das Relações Exteriores, é responsável por esses assuntos, o que incluiria todo um trâmite por dentro da UFRJ e pela Fundação Universitária José Bonifácio (FUJB) que nos criaria muitos problemas. ${ }^{44}$

42 Os textos dos projetos das duas etapas do Trilhas de Conhecimentos enviados à PHEI/FF por intermédio do escritório do Rio de Janeiro e o roteiro para a apresentação de propostas encontram-se disponíveis em Souza Lima e Barroso (2017).

43 Fomos alertados pela Professora Yonne Leite, que fora informada por uma sobrinha funcionária do BID sobre esse edital, que sabia que preparávamos o projeto. Os recursos do Fundo de Inclusão Social do BID para essa finalidade eram provenientes da Noruega que, como mencionei, era um dos principais financiadores de trabalhos de ONGs com povos indígenas no Brasil. É ainda importante ter em mente que também foram recursos do Fundo de Inclusão Social que serviram para a estruturação da Secadi, anteriormente mencionada, e que as técnicas da representação do BID para as duas ações eram as mesmas.

44 Para o site oficial da ABC, ver http://www.abc.gov.br/ (acessado em 07/09/2017). 
Após idas e vindas durante mais de um mês, acertamos com as técnicas do BID responsáveis pelo projeto que elas próprias executariam os recursos, o que terminou por ser providencial por três razões: pelo fato de serem reduzidos, porque desejávamos reunir em Brasília uma quantidade expressiva de atores sociais e também porque - e assim aprenderíamos ainda outra lição, a dos limites de certos técnicos de fundações universitárias - as passagens agendadas pelo setor responsável da FUJB através da agência de viagem com a qual operavam estavam todas com custos "cheios". Após todas as diversas mudanças no plano de gestão que tivemos de realizar, e termos conseguido, por fim, sensibilizar o escritório da FF para a disponibilização de uma pequena parte dos recursos do PTC para essa atividade, o seminário aconteceu em Brasília, nos dias 30 e 31 de agosto de 2004, com o título Desafios para a Educação Superior dos Povos Indígenas no Brasil. Tratou-se da primeira reunião ampla com essa finalidade precípua, contando com a participação de organizações e intelectuais indígenas, setores governamentais, organizações não governamentais, organismos de fomento e docentes universitários, originando um relatório, depois transformado em publicação. Os debates então acontecidos e documentados não só delinearam um momento histórico específico como colocaram questões ainda hoje pertinentes, como as dos meios materiais insuficientes para a manutenção de indígenas em universidades públicas, assim como aquelas relativas às diferenças entre ações afirmativas para indígenas e para negros, dentre muitas outras.

Além da presença de Ricardo Henriques, secretário da recém-criada Secad, também conseguimos contar com a participação na mesa de abertura do então secretário de Educação Superior do Ministério da Educação, o Professor Nelson Maculan, ex-reitor da UFRJ, fato raro em todos os anos em que trabalhamos diretamente com essa questão. ${ }^{45} \mathrm{~A}$ Sesu sempre esteve ausente ou, no mínimo, pouco presente, mesmo quando estava designada em portarias e outros documentos como coparticipante ou corresponsável por ações para o ensino superior de indígenas. Para tanto, foram sem dúvida determinantes $o$ nosso pertencimento ao Museu Nacional e o fato de que a equipe de Maculan era integrada por Renata Gerard Bondim, linguista com informação sobre

45 Para a programação do seminário, ver Souza Lima e Barroso-Hoffmann (2007). 
as questões relativas às línguas indígenas no Brasil, professora aposentada da UFRJ, da qual foi superintende de Pesquisa e Pós-Graduação, na época consultora para questões relativas à língua portuguesa da Comissão de Língua Portuguesa do MEC, e que depois assumiria atividades relativas à educação superior de indígenas na Sesu.

A realização do seminário estimulou a Sesu e a Secad a tomarem posição, finalmente, no tocante à educação superior de indígenas. Assim, Renata Bondim apresentou no seminário (Bondim, 2007) o desenho da proposta que geraria, um ano mais tarde, o primeiro edital de convocação do Programa de Apoio à Educação Superior e Licenciaturas Indígenas (Prolind) em 2005. ${ }^{46}$ Integrei o comitê técnico multidisciplinar, como representante da ABA, desde a sua primeira edição, em 2005, até a última, em 2014. Em 2006, de 30/11 a 02/12, realizamos, em parceria com a Secad, a Sesu, a ABA (eu era nesse momento coordenador da Comissão de Assuntos Indígenas, na gestão de Luis Roberto Cardoso de Oliveira) e a UnB, o Seminário Nacional de Avaliação do Programa de Formação Superior e Licenciaturas Indígenas. ${ }^{47}$

A implementação do Prolind constitui em si matéria para um trabalho de fôlego, o que não pretendo fazer aqui. Cabe, no entanto, dizer que, apesar dos diversos percalços nesse processo, a começar pelos fundos relativamente escassos para a dimensão da tarefa, devido à sua implantação por intermédio de editais, e a difícil mecânica de repasses entre MEC e universidades estaduais, dentre muitos outros, o Prolind chegou a financiar 27 universidades estaduais e federais, bem como institutos federais de tecnologia e, segundo dados apresentados pela Assessoria de Comunicação do MEC, são hoje 17 os cursos de licenciatura intercultural vigentes (Brasil, 2017).

46 Ver Souza Lima e Barroso-Hoffmann (2007), mencionado anteriormente. Sobre a atuação da Sesu, através de seu Departamento de Política da Educação Superior (Depes), ver Bondim (2006, 2007, 2013). Para o Prolind, ver Barnes (2010) e http://portal.mec.gov.br/prolind e https://ensinosuperiorindigena.wordpress.com/atores/nao-humanos/prolind-2/ (acessados em 07/09/2017). Há muito mais material disponível on-line, apesar de não sistematizado. O site de alunos da Universidade de São Paulo (USP) https://ensinosuperiorindigena.wordpress.com/ (acessado em 07/09/2017) é a melhor sistematização de dados básicos até o momento. Para o edital de convocação $\mathrm{n}^{\circ}$, de 29 de junho de 2005, ver Brasil (2005); para o edital de convocação $\mathrm{n}^{\circ} 3$, de 24 de junho de 2008, ver Brasil (2008); para o edital de convocação nº 8, de 27 de abril de 2009, ver Brasil (2009), para o edital de convocação $n^{\circ} 2$ de 27/08/2013, ver Brasil (2013b).

47 Para a programação do seminário, ver http://portal.mec.gov.br/sesu/arquivos/pdf/PROLIND/ seminario_avaliacao_programacao.pdf (acessado em 07/09/2017). 
Em paralelo à preparação da equipe, desenvolvemos as negociações com a Fundação Universitária José Bonifácio, pessoa jurídica de direito privado que tem como objetivo dar suporte aos projetos de pesquisa, ensino e extensão da UFRJ, atuando formalmente como o agente fiscal responsável por administrar a doação da FF. A fundação receberia os recursos que seriam oportunamente destinados aos núcleos de outras universidades que desenvolveriam o trabalho junto aos indígenas. ${ }^{48} \mathrm{O}$ escritório da $\mathrm{FF}$ insistiu que os pagamentos de pesquisadores deveriam ser feitos sob a modalidade de bolsas, de modo a evitar sua sangria com o pagamento de impostos, o que implicou o estabelecimento de um programa de bolsas até então inexistente pela FUJB, o que não foi exatamente nem simples, nem rápido.

Ademais, receber recursos e repassar a outras fundações não era, nem é, uma atividade usual às fundações universitárias, sendo que à FUJB, com a mediação da nossa equipe, caberia fazer a supervisão contábil de toda atividade que viesse a ser desenvolvida pelos núcleos a serem criados. Isso se tornou ainda mais complicado na medida em que os recursos recebidos pelo Laced, destinados à sua equipe e à distribuição entre os núcleos, eram liberados em dólar e transferidos ao câmbio do momento da liberação (necessariamente parcelada pelos acertos com a FF) para uma conta bancária do Banco do Brasil, cujo titular era a FUJB. Na prática, isso significava que, a depender do câmbio, teríamos mais ou menos dinheiro em reais. Se, na maior parte dos projetos que coordenei ou cocoordenei com recursos da $\mathrm{FF}$, o real estava relativamente depreciado em relação ao dólar, e a aplicação dos recursos em fundos financeiros por longo tempo permitia fazer render o dinheiro - e assim realizar mais atividades - durante o PTC deu-se o inverso: o cálculo do total do projeto, com as quantias que seriam alocadas aos núcleos, foi feito em cima de uma taxa de câmbio de cerca de US\$ 1,00/R\$ 3,20. O primeiro desembolso da parte específica do Laced em 12/03/2004 deu-se a uma taxa de câmbio de US\$ 1,00/R\$ 2,89; o desembolso seguinte, em 16/03/2005, deu-se a uma taxa de US\$1,00/R\$ 2,72 e, em 2005, a taxa chegou a US\$1,00/ R\$2,18. Em 2006 a taxa foi para US\$ 1,00/ $\mathrm{R} \$ 2,15$ e, no ano de 2007, chegou a US\$ 1,00/R\$ 1,77. E seria a partir de 2005 que os repasses a outras universidades seriam feitos.

48 Para a página web da FUJB, ver http://www.fujb.ufrj.br/sobre-a-fujb/ (acessado em 07/09/2017). 
Nem nós, nem a FUJB estávamos preparados para atuar como uma (micro) carteira de fomento. Tanto mais que o escritório da $\mathrm{FF}$ foi incisivo no sentido de que a porcentagem relativa à taxa de administração a ser destinada à FUJB incidisse apenas sobre os US\$ 356 mil relativos à parte do Laced, e não como usualmente o seria, incidindo sobre todo o dinheiro da doação (os US\$ 1,2 milhão). A FUJB, no entanto, deveria supervisionar a contabilidade das universidades que recebessem as doações feitas pelo projeto. Não foi, portanto, surpreendente que em 2007 tivéssemos de fazer uma espécie de "auditoria interna" para reaver parte dos recursos referentes a cobranças de taxas indevidas, uma quantia que teria impossibilitado os demais trabalhos da equipe do Laced. Tampouco foi surpreendente que durante parte ponderável da primeira doação não contássemos com a "boa vontade" do pessoal da FUJB que lidava diretamente com a doação, o que nunca antes se dera. Essa foi sem dúvida uma parte pouco "glamorosa", "heroica" ou produtiva em termos das finalidades últimas do PTC e que exigiu um grande esforço. No entanto, a gestão do projeto em termos financeiros foi em si mesma estratégica. Para tanto, contei com o fato de já ter tido experiência com a gestão de recursos de grandes equipes anteriormente, com o apoio operacional de Afonso Santoro, com o diálogo com Aurélio Vianna Jr. que, a partir de sua entrada em 2005, facilitaria consideravelmente essa atividade. Pensando retrospectivamente, creio que esse e outros momentos difíceis foram superados, meu temperamento obstinado à parte, em função do meu interesse intelectual pela administração pública e pela cooperação técnica internacional, além da disposição presente no fazer etnográfico de pensar a partir de múltiplas situações, inclusive adversas (aliada a uma experiência pessoal e profissional marcada pelo necessário enfrentamento de dificuldades de diversas ordens), somados à disposição em facilitar as condições de trabalho dos núcleos junto aos indígenas de modo a que se beneficiassem ao máximo do projeto. Como tínhamos claro que tais quantias, por mais vultosas que fossem à época, jamais supririam as políticas governamentais que precisavam ser estabelecidas, era fundamental que elas servissem a ações que inspirassem outras iniciativas de universidades que não estávamos fomentando e que - éramos conscientes disso - seguiam um curso paralelo ao do PTC, mas que poderiam confluir, a partir dos interesses de indígenas e docentes universitários (dentre os quais se achavam muitos antropólogos), para políticas que generalizassem essas modalidades de ação afirmativa. 
Desde o início de 2004 até o final de 2005, também foram realizados inúmeros contatos com universidades e organizações indígenas, incentivando-as à apresentação de propostas, o que envolveu viajar quase que o tempo todo e, ao mesmo tempo, manter a atividade docente. A partir desse trabalho de indução à demanda, foram aprovadas até o final do período as propostas para a criação de dois núcleos envolvendo três universidades. Essas experiências-modelo ocorreram em uma universidade federal, a Universidade Federal de Roraima, por meio de seu Núcleo (hoje Instituto), Insikiran de Formação Superior Indígena, com o projeto denominado Programa E'ma Piá, e em outro núcleo, o Programa Rede de Saberes, que articulou duas outras universidades, sendo uma estadual, a Universidade Estadual do Mato Grosso do Sul (ambas públicas e não pagas) e uma universidade privada confessional, a Universidade Católica Dom Bosco (UCDB). ${ }^{49}$

A escolha das propostas deveu-se não apenas à qualidade das mesmas, mas também ao fato de que fosse em Roraima, fosse no Mato Grosso do Sul, havia um significativo número de estudantes indígenas matriculados nas universidades (na UFRR e na Uems, esta última uma das pioneiras na definição de cotas na graduação, no enfrentamento de problemas nos vestibulares e outras questões) e relativo acúmulo de conhecimento no trato de dimensões políticas da situação indígena (no caso da UCDB, pelo Núcleo de Estudos e Pesquisas das Populações Indígenas - Neppi - liderado por Antonio Jacó Brand). ${ }^{50}$

49 Sobre o Programa E'ma Piá, ver Fernandes, Carvalho e Repetto (2017). Para o Programa Rede de Saberes, ver Aguilera Urquiza et al. (2017); Vianna et al. (2014) e Aguilera Urquiza e Nascimento (2013). O Programa Rede de Saberes também passou, em sua segunda fase, de 2007 em diante, a incorporar ações na Universidade Federal do Mato Grosso do Sul (UFMS) e na Universidade Federal da Grande Dourados (UFGD). Devo registrar que a Fundação Ford, a partir de 2005, faria outros investimentos em organizações indígenas situadas no estado de Roraima que, por se situar na Amazônia, estava em sua área de atuação possível. Para a página do Programa Rede de Saberes (bastante desatualizada), ver http://neppi.org/rededesaberes/ (acessado em 07/09/2017).

50 Antonio Jacó Brand, 13/09/1949-04/07/2012, foi historiador e professor da Universidade Católica Dom Bosco, o que é dizer muito pouco de sua enorme atividade em prol dos povos indígenas. Foi secretário nacional do Conselho Indigenista Missionário (Cimi) de 1983 até o início dos anos 1990, tendo atuado intensamente durante o período da Assembleia Nacional Constituinte de 1987 em favor da definição constitucional dos direitos indígenas. Sua ação indigenista precede a criação do Cimi, em 1972, tendo sido responsável pela instalação do mesmo no Mato Grosso do Sul. Sua conexão com os Guarani do Mato Grosso do Sul era intensa. Sua tese de doutorado, focada no que denominou confinamento desse povo e nas consequências desse processo 
Duas outras propostas (uma delas submetida duas vezes) de universidades e uma pré-proposta de outra universidade, todas federais, não foram plenamente desenvolvidas por desistência das mesmas em face das exigências apresentadas às suas primeiras formulações. Uma vez definidos os núcleos, passamos a realizar o acompanhamento de suas ações, avaliando-os de modo participativo e integrado, na tarefa de criar e manter programas destinados a estudantes indígenas portadores do título de conclusão do ensino médio, visando sua preparação para o exame vestibular e seu acompanhamento tutorial na universidade.

Além de ações voltadas para a licenciatura intercultural, o Programa E'ma Piá também desenvolveu outras, que visavam propiciar a presença indígena nos cursos regulares da universidade, criando-se uma estrutura de suporte até então inexistente e abrindo-se uma vaga para estudantes indígenas em todos os cursos da UFRR. Atualmente há um processo seletivo indígena específico regulado pela comissão de vestibular da universidade..$^{51} \mathrm{O}$ programa existiu apenas até o final da primeira etapa do Trilhas pois, por divergências institucionais internas ao Insikiran, não houve interesse em levar o trabalho adiante.

No caso do Programa Rede de Saberes, deu-se o exato oposto. À experiência do Neppi/UCDB na questão indígena, aliaram-se o comprometimento e o afinco de Beatriz Landa na Uems, além do forte engajamento dos estudantes indígenas, o que resultou numa dinâmica que faria expandir em muito as suas atividades. Por não contarem com um curso de licenciatura intercultural nessa primeira etapa, as ações do projeto atingiram estudantes de uma ampla gama de cursos nas duas universidades, lançando as bases para uma segunda

de expropriação fundiária, foi fundamental em muitos processos de recuperação de terras, o que sempre lhe valeu uma forte pressão política dos ruralistas do Mato Grosso do Sul. Portador de fina percepção política, grande capacidade diplomática e larga experiência, já era um interlocutor fundamental de nossas ações no Laced, antes mesmo de pensarmos na possibilidade de instalação de um núcleo interinstitucional no Mato Grosso do Sul. Sua posição no cenário indigenista era única e sua perda, irreparável. Para mais dados sobre sua trajetória, ver Junges (2012) e Silva, M. (2012), e para um vídeo em homenagem póstuma, ver https://www.youtube. com/watch?v=6ERoektax8E (acessado em 07/09/2017).

51 Para o manual para candidatos indígenas ao processo seletivo específico, ver http://ufrr.br/cpv/ index.php?option=com_phocadownload\&view=category\&download=892:manual-do-candidato-psei-2018\&id=93:vestibular-indigena-2018\&Itemid=301 (acessado em 07/09/2017). 
etapa que abarcaria mais duas universidades.$^{52} \mathrm{~A}$ ação dos estudantes indígenas na Uems, iniciada antes da instalação do projeto, através da reivindicação ao governo estadual de um suporte por meio de bolsas, foi essencial para o sucesso das ações do Rede de Saberes. Vimos formar-se um conjunto geracionalmente diferenciado de atores indígenas, jovens que viram na universidade um caminho viável para a assunção, inclusive de papéis políticos de grande importância em nível local e nacional. ${ }^{53}$ Alguns deles participariam da articulação dos Encontros Nacionais de Estudantes Indígenas (Eneis), cuja primeira edição ocorreu na Universidade Federal de São Carlos, em 2013, eventos nos quais as ações afirmativas para indígenas são debatidas, assim como aspectos mais gerais das questões indígenas. ${ }^{54}$ Para muitos dos estudantes formados no Programa Rede de Saberes, as tecnologias digitais de comunicação e as redes sociais - de resto como num espectro social mais amplo que o dos povos indígenas, por si só extremamente diverso - foram instrumentos de articulação e de posicionamento político, de interação, de estabelecimento de novas relações e de sociabilidade muito importantes. ${ }^{55}$

Diversas foram as atividades desenvolvidas pelo Programa Rede de Saberes que, após essa etapa inicial, receberia mais dois financiamentos da Fundação Ford/PHEI. Mas, sem sombra de dúvidas, foram fundamentais a articulação institucional, local, regional e nacional, bem como a abertura de espaços para

52 Ver Aguilera Urquiza et al. (2017), Vianna e al. (2014) e Aguilera Urquiza e Nascimento (2013). Para um vídeo sobre o Programa Rede de Saberes, consultar https://www.youtube.com/ watch?v=dwOLOqmCgJM. Para diversos depoimentos de estudantes indígenas que passaram pelo programa, ver os vídeos no canal do Neppi no YouTube: https://www.youtube.com/channel/UCtWtmP5aHSK-OUUloL7oKwg (acessados em 07/09/2017).

53 Ver Amado (2016). Simone Eloy Amado é uma liderança importante no contexto do Mato Grosso do Sul e foi organizadora do II Enei, realizado em Campo Grande, nas dependências da UCDB, de 4 a 7 de agosto de 2014. Sobre o II Enei, ver https://enei2014.wordpress. com/2014/04/27/ii-enei-ii-encontro-nacional-de-estudantes-indigenas/ e https://www.youtube.com/watch?v=BBVVq5ouVdo. Para um vídeo com Simone sobre seu trabalho mais recente com mulheres indígenas, ver https://www.youtube.com/watch?v=_N7Tti-VHzc (acessados em 07/09/2017).

54 Para uma sessão do I Enei na qual se discutiram especificamente as ações afirmativas, ver https://www.youtube.com/watch?v=3c-rRObRWPo (acessado em 07/09/2017).

55 Ver Oliveira (2015). Em projeto posterior ao Trilhas, desenvolvido com a intenção de fornecer material ao trabalho de pesquisadores e atores políticos indígenas, investimos em realizar uma oficina sobre tecnologias digitais e em publicar um texto de referência para esse tipo de atividade de comunicação. Ver Oliveira (2014). 
que os estudantes indígenas em formação pudessem exercitar as atividades universitárias, especialmente por meio da iniciação à pesquisa e de tutorias e cursos específicos. ${ }^{56}$ Muitos dos estudantes indígenas que saíram das graduações das universidades filiadas ao programa engrossariam as fileiras dos cursos de pós-graduação, independentemente de outras inserções profissionais. Creio que seria valiosa uma recuperação histórica mais densa dos efeitos sociais desse trabalho, em particular abordando o destino dos egressos, mais de uma década após o seu início.

Era ainda nossa tarefa dialogar com a avaliação independente - tanto de nosso trabalho quanto da ação dos núcleos - contratada pela Fundação Ford às Professoras Vanilda Paiva e Azuete Fogaça e realizada ao longo de 20072008. A avaliação brasileira correria paralela a uma avaliação para os programas Pathways da América Latina, elaborada pelos pesquisadores Sylvie Didou Aupetit e Eduardo Remedi Allione, ambos do Centro de Investigación y de Estudios Avanzados del Instituto Politécnico Nacional (Cinvestav), no México.57

56 O depoimento de Luiz Henrique Eloy, que foi representante de alunos indígenas no Programa Rede de Saberes, é eloquente e sintetiza o trabalho do programa de modo muito feliz. Está disponível em https://www.youtube.com/watch?v=Hp_NxluVuo4. Para uma narrativa autobiográfica do hoje advogado da Articulação dos Povos Indígenas no Brasil (Apib), doutorando em Antropologia do PPGAS/Museu Nacional, com expressão nacional no Brasil, ver https://www. youtube.com/watch?v=lnRmej4mZUk (acessados em 07/09/2017).

57 Para os currículos Lattes de Vanilda Paiva e Azuete Fogaça, ambos desatualizados (o que significa que estão em alguma medida desvinculadas de programas de pós-graduação), ver http:// lattes.cnpq.br/2175362065247859 e http://lattes.cnpq.br/9027607698896030. Para Sylvie Didou Aupetit, ver http://www.die.cinvestav.mx/Personal-Academico/Dra-Sylvie-Didou-Aupetit e para Eduardo Remedi Allione, ver http://www.die.cinvestav.mx/Personal-Academico/Dr-Eduardo-Remedi-Allione (acessados em 07/09/2017). Estes dois últimos pesquisadores publicaram um livro a partir do material da avaliação (Didou Aupetit; Remedi Allione, 2010). Ainda que aquela não fosse sua área original de pesquisa, Sylvie Didou Aupeti aproveitou-se da avaliação que realizou para constituir uma linha de pesquisas e se articular a redes latino-americanas de profissionais da educação superior engajados em ações afirmativas na educação superior para povos indígenas (ver Didou Aupetit, 2014). Em Didou Aupetit e Gérard (2009), coletânea sobre a "fuga de cérebros na América Latina", encontramos diversos autores que nos ajudam a situar a rede de conexões dessa pesquisadora, dentre eles o pesquisador argentino Jorge Balán (ver https:// sipa.columbia.edu/faculty-research/faculty-directory/jorge-balan-0 - acessado em 07/09/2017), que fora senior program officer em Educação Superior da FF, assim como Ana Garcia de Fanelli, pesquisadora argentina da mesma área, contratada para fazer a avaliação do "Pathways chileno". O pesquisador brasileiro presente na mesma coletânea é Simon Schwartzman. 
No trabalho com os núcleos, devíamos coordenar esforços de ação em rede com outras universidades, no sentido de acumular e potencializar a capacidade operacional e investigativa que pudesse contribuir para a mudança das instituições de ensino superior, de modo a torná-las plurais e democráticas e, simultaneamente, mais qualificadas e melhores, assim como sua prática mais bem conhecida. Essa função de mediação entre a FF e as universidades só fazia sentido, no nosso entender, se nos deslocássemos das mesmas, passando às universidades os conhecimentos necessários para a interlocução com a real financiadora. Dada a larga experiência como grantee (financiado) da FF, sempre insistimos que esse "dinheiro-semente" (seed money) acabava e era insuficiente, por mais que fosse vultoso para os padrões brasileiros e para aqueles da própria financiadora, diante da tarefa de um programa continuado de ações afirmativas. A alternativa sempre foi, de nosso ponto de vista, a busca por políticas federais de fomento e ações de incentivo às ações afirmativas. Antonio Brand e os demais colegas do Rede de Saberes, juntamente com os acadêmicos indígenas, foram extremamente atentos e perseverantes nessas reivindicações.

Foram feitas, ainda, outras duas subdoações. Com elas, nossa intenção era - já que a queda do câmbio fizera com que os recursos a serem doados encurtassem e que julgássemos mais pertinente ter menos universidades engajadas, porém mais bem financiadas - envolver duas outras universidades federais localizadas em regiões nas quais não tínhamos ações, de modo a atingir centros onde a presença indígena era significativa, promovendo seminários em parceria. Juntávamos a necessidade de fomentar a discussão sobre ações afirmativas para os povos indígenas com a busca por formação em áreas disciplinares que, em muitas regiões do Brasil, eram muito refratárias à presença de estudantes indígenas - o direito e a medicina - mas especialmente interessante para eles, com o acúmulo de experiências e reflexões de certas universidades.

Assim, fizemos uma subdoação ao Programa de Pós-Graduação em Direito da Universidade Federal do Pará (PPGD/UFPA), para a promoção de um seminário sobre Formação Jurídica e Povos Indígenas: Desafios para uma Educação Superior no Brasil, tendo à frente da iniciativa a Professora Jane Felipe Beltrão. ${ }^{58} \mathrm{O}$ seminário contou, também, com o apoio da ABA e do Ministério

58 Eu já trabalhara com Jane Felipe Beltrão durante o período em que fui vice-presidente da ABA e ela, integrante de seu Conselho Fiscal. Desde então mantivemos contato e buscamos 
Público Federal. ${ }^{59}$ Em 2004, o PPGD ganhou um edital para a criação de cursos de direitos humanos, lançado pela Fundação Carlos Chagas, com recursos da Fundação Ford. O referido programa abria cotas para alunos indígenas e negros e investia num diálogo denso com a antropologia, no qual Jane Beltrão teve um papel central, o que lhes permitiu uma área de concentração sólida em direitos humanos e um trabalho pioneiro em ações afirmativas na pós-graduação. ${ }^{60}$ O seminário ocorreu nos dias 21-23/03/2007, tendo agregado integrantes de diversas organizações indígenas, estudantes indígenas que já frequentavam cursos de direito, docentes de universidades (dentre elas, as envolvidas nos núcleos financiados), procuradores da República e representantes de agências de Estado e de organizações não governamentais conectadas às questões indígenas, dentre outros. ${ }^{61}$ Em termos imediatos, o seminário desdobrou-se em um curso de formação de alunos indígenas em direitos indígenas, no âmbito do Programa Rede de Saberes, fruto da reivindicação desses estudantes indígenas do Mato Grosso do Sul, que se repetiria mais tarde contando com a participação decisiva da assessoria jurídica do Cimi. No âmbito da própria UFPA, o seminário também deu ensejo a uma interlocução com a Fundação Ford que desaguou no já citado (nota 37) Programa de Políticas Afirmativas para Povos Indígenas e Populações Tradicionais (Papit), que encabeçou o debate para a extensão das ações afirmativas a indígenas e "povos tradicionais" na UFPA. A doação ao Papit/UFPA foi feita ainda com recursos da PHEI em 2008, diretamente pelo escritório do Rio de Janeiro, sob a responsabilidade de Aurélio Vianna Jr. A partir do Papit, na época, sob direção de Jane Beltrão, deu-se ensejo

trabalhar em conjunto em diferentes ocasiões, como nesse seminário. Em 2015-2016, quando fomos presidente e vice-presidente da $\mathrm{ABA}$, tínhamos já uma considerável estrada de amizade e colaboração. Essa breve nota é um pálido reflexo de uma relação especialmente afetiva, rica e construtiva, nos planos intelectual e pessoal.

59 Transcorria a gestão de Luis Roberto Cardoso de Oliveira à frente da ABA, e eu era o coordenador da Comissão de Assuntos Indígenas, além de representar a instituição no comitê técnico do Prolind, junto ao MEC. Luis Roberto esteve presente tanto nesse seminário quanto naquele sobre formação em saúde, do qual tratarei a seguir.

60 Para o PPGD e a área de direitos humanos, ver http://www.ppgd.propesp.ufpa.br/index.php/br/ e http://www.ppgd.propesp.ufpa.br/index.php/br/impacto/interacoes-com-organizacoes-nao-academicas (acessados em 07/09/2017).

61 Para o seminário, ver http://www.ufpa.br/juridico/ (acessado em 07/09/2017). Ver também Beltrão (2017). O seminário foi todo filmado e foram feitas e distribuídas cópias das gravações por sessões. 
à criação, no campus da UFPA em Altamira, do curso de graduação em Etnodesenvolvimento, experiência pioneira de significativa importância, destinada a indígenas, quilombolas e povos tradicionais. Hoje o Bacharelado em Etnodesenvolvimento e a Licenciatura em Educação do Campo integram a Faculdade de Etnodiversidade. ${ }^{62}$

O curso de Bacharelado em Etnodesenvolvimento vem tendo uma ponderável repercussão na Amazônia, constituindo um dos suportes à transposição de algumas propostas de ações afirmativas para coletividades que, até então, não reivindicavam uma educação superior específica e que, por direito, são detentoras do acesso às terras que tradicionalmente ocupam, como no caso de quilombolas e outros povos tradicionais. Ademais, em recente avaliação do MEC, o referido curso logrou nota 4. De certo modo, essa foi também uma das formas a partir das quais pudemos ver recuperado um diálogo com outras atividades anteriormente realizadas, como os cursos de especialização em gestão para o etnodesenvolvimento da Ufam anteriormente mencionados, bem como a destinação inicial pensada por José Gabriel Lopez para o Trilhas, que também deveria ter se aberto para os integrantes de comunidades extrativistas amazônicas. ${ }^{63}$

O segundo seminário intitulou-se Formação Universitária Indígena em Saúde: Desafios para uma Educação Superior para os Povos Indígenas no Brasil e foi realizado em Porto Seguro, de 16-19/05/2007, em parceria com a Universidade Federal da Bahia (UFBA) (Museu de Arqueologia e Etnologia), donatária de subdoação, com a UFPA, e a Fiocruz-Amazônia, contando com o apoio da Associação Brasileira de Antropologia e da Associação Brasileira de Saúde Coletiva (Abrasco). A área de saúde coletiva da UFBA, hoje um instituto, já contava com o grau 7, máximo, nas avaliações da Capes, e mantém atualmente o que na época era um projeto e uma das razões da nossa busca por parceria e interlocução - eles haviam concebido a ideia de uma graduação em Saúde Coletiva, que seria lançada em 2009, o que nos parecia uma excelente entrada para os

62 Ver http://altamira.ufpa.br/index.php?option=com_content\&view=article\&id=25\&Itemid=19 (acessado em 07/09/2017).

63 O curso e as variadas implicações nele contidas estão refletidos no volume organizado por Assis da Costa Oliveira e Jane Felipe Beltrão (2015), intitulado Etnodesenvolvimento e universidade: formação acadêmica para povos indígenas e comunidades tradicionais. Para a relação entre quilombos e o que se convencionou chamar de "novas etnias", ver Almeida, A. (2002). 
indígenas que queriam trabalhar na gestão de distritos sanitários e não necessariamente como enfermeiros ou médicos.

O seminário foi concebido e coordenado por Carlos (Alberto) Caroso (Soares), (Maria) Luiza Garnelo (Pereira), Jane Beltrão e por mim. ${ }^{64} \mathrm{Na}$ época, o grupo de docentes de saúde coletiva da UFBA idealizara e vinha propondo à discussão, num modelo bastante distinto dos cursos até então existentes, uma graduação em sanitarismo, que pensamos ser uma base útil para as discussões de modelos diferenciados de cursos para indígenas na área de saúde. Em meio a essa ideia estava Naomar Almeida Filho, docente do Programa de Pós-Graduação em Saúde Coletiva e reitor da UFBA, um dos responsáveis pela concepção de um projeto alternativo para as universidades federais, denominado "Universidade Nova", forma pensada para flexibilizar as rígidas estruturas curriculares e a excessiva disciplinarização diante das demandas crescentes de áreas de interface. ${ }^{65}$ Discutia-se ainda, naquela ocasião, a implantação de um campus da UFBA em Porto Seguro, que ensejaria a criação, anos mais tarde, da Universidade Federal do Sul da Bahia (UFSB), da qual Almeida Filho se tornou o primeiro reitor, e Carlos Caroso o decano pro tempore do Centro de Formação em Ciências Humanas e Sociais. O sul da Bahia é uma região importante para os povos indígenas desse estado e do Nordeste, assim como de Minas Gerais e do

64 Carlos Alberto Caroso Soares já era nosso interlocutor desde a realização da Reunião Brasileira de Antropologia (RBA) de Salvador, em 1996, e acolheu prontamente a nossa ideia. Ele próprio, na época diretor do Museu de Arqueologia e Etnologia da UFBA, visualizava a região de Porto Seguro como um sítio estratégico para o desenvolvimento de ações afirmativas no tocante aos povos indígenas pela UFBA. Lembremos que estávamos em meio à efervescência da luta por cotas nas universidades, que a Universidade do Estado da Bahia tinha sido uma das pioneiras na região e que, em 2009, implantaria um curso de licenciatura intercultural contemplado em um edital do Prolind. No ano seguinte, 2008, seria realizada em Porto Seguro a XXVI RBA. Maria Luiza Garnelo Pereira, na época, ainda docente da Universidade Federal do Amazonas e já Pesquisadora do Instituto Leônidas e Maria Deane/Fiocruz-Amazônia havia sido representante da ABA na Comissão Intersetorial de Saúde Indígena (Cisi)/Conselho Nacional de Saúde-Ministério da Saúde. Participara como docente do curso de Especialização em Gestão para o Etnodesenvolvimento em 2002-2003, durante a gestão de Gustavo Lins Ribeiro à frente da ABA, tendo sido uma das minhas principais colaboradoras no tocante à Comissão de Assuntos Indígenas que também coordenei de 2002 a 2004, período em que organizou em Manaus o seminário sobre mulheres indígenas e saúde, uma das primeiras iniciativas sobre essa temática no Brasil. Em 2007, foi diretora regional da ABA para a região Nordeste. Esteve também presente no seminário Carla Costa Teixeira (UnB), então secretária da ABA, que coordenou um dos grupos de trabalho do mesmo.

65 Ver Almeida Filho (2007). 
Espírito Santo. ${ }^{66}$ O campus do sul da Bahia da UFBA e depois a UFSB, quando criada, se tornaram importantes pontos de formação indígena no cenário do Nordeste, no meio de uma das regiões de maior violência na vida dos povos indígenas no Brasil.

Era, ainda, parte de nossa tarefa dar suporte aos núcleos também na disseminação de conhecimentos básicos à formação política dos indígenas no tocante aos seus direitos e às políticas governamentais a eles destinadas, contribuindo para que se articulassem a organizações indígenas, dentre outras coisas, no fomento, acompanhamento e debate das políticas governamentais que os afetam. Tratava-se de se articular à demanda dessas organizações por profissionais indígenas capacitados no nível do terceiro grau, mas numa perspectiva que vinha sendo recoberta pela ideia de interculturalidade, de modo a influenciar as políticas públicas, construindo as bases sociais da sustentabilidade dessas iniciativas, bem como seus conteúdos propriamente indígenas. ${ }^{67}$

Diante disso, desenvolvemos algumas atividades, tanto no PTC em suas duas etapas quanto em projetos posteriores. Assim, ao longo de 2005 e até o final de 2006, contratamos a elaboração de quatro livros paradidáticos destinados especialmente à formação superior de indígenas. Não havia e ainda há muito pouco material que seja útil a certos objetivos de formação intelectual e política de indígenas. Quando existentes, são em geral escritos por não índios. Visando sua máxima distribuição, planejamos uma série de livros a ser divulgada on-line sob a forma de e-books e negociamos sua publicação em tiragens de cinco mil exemplares de cada volume, destinados à distribuição nacional para escolas indígenas, alunos indígenas de cursos universitários de todas as carreiras, organizações indígenas, agências da administração pública envolvidas com as questões indígenas, ONGs indigenistas, bibliotecas públicas, etc.,

66 Para o relatório do seminário, que também foi gravado em vídeo, ver Caroso e Losada (2017).

67 Já se verteu muita tinta sobre a ideia de interculturalidade e não pretendo aqui dar conta dessa discussão que, no caso brasileiro, muitas vezes me soou insubstancial. Uma coletânea organizada por mim, Gustavo Lins Ribeiro e Luis Felipe Carvalho com textos sobre a chamada educação intercultural no nível universitário em países da América Latina - sobre a qual há muita coisa escrita - está em vias de publicação pela editora Contra Capa Livraria. Para uma bem-sucedida adaptação de programas universais para as especificidades da situação indígena, no caso do Programa de Educação Tutorial/Conexões de Saberes, ver Freitas (2015). 
com a Coordenação Geral de Educação Escolar Indígena (CGEEI/Secad), que tinha respectivamente à sua frente Kleber Gesteira Matos e André Luiz de Figueiredo Lázaro. ${ }^{68} \mathrm{~A}$ série por nós coordenada dentro da "Coleção Educação Para Todos", da Secad/MEC, em conjunto com a Unesco, foi intitulada "Vias dos Saberes". À Secad/MEC e à Unesco coube o pagamento da impressão, a nós, a remuneração dos autores, o projeto gráfico adaptado à coleção e a editoração. Tal gênero de textos tem sido usualmente escrito por não indígenas. Nessa série, tendo sido definida desde a concepção do projeto, julgamos que seria importante buscar sempre que possível autores indígenas, de forma a mostrar a viabilidade de uma imagem positiva de uma "intelectualidade indígena" com a qual dialogar.

O primeiro livro da série é uma introdução geral aos aspectos da vida dos povos indígenas no Brasil contemporâneo, escrita por uma de suas principais lideranças de projeção nacional, o já citado Gersem Luciano Baniwa (Luciano-Baniwa, 2006), integrante do nosso comitê assessor e, na ocasião, já mestre em Antropologia e ex-bolsista do IFP. O segundo livro da série (Pacheco de Oliveira; Rocha Freire, 2006), escrito pelos antropólogos João Pacheco de Oliveira (Museu Nacional/UFRJ) e Carlos Augusto da Rocha Freire (Museu do Índio/ Fundação Nacional do Índio - MI/Funai), é um trabalho sem similar até hoje em nossa produção acadêmica, apresentando de modo crítico e didático a

68 Segundo o texto informado em seu CV Lattes, Kleber Gesteira e Matos é "Mestre em Ciências Sociais pelo Centro de Pesquisa e Pós-Graduação sobre as Américas da Universidade de Brasília (CEPPAC/UNB) e licenciado em Física pela Universidade Federal de Minas Gerais. Em 2014, trabalhou no Ministério da Educação, inicialmente, como Assessor do Gabinete da SECADI e a seguir como Diretor de Políticas de Educação e Direitos Humanos. Entre 2011 e 2012, integrou a Equipe Educativa do Espaço UFMG do Conhecimento, do Circuito Cultural da Praça da Liberdade. Entre 2008 e 2010, integrou a equipe de execução de Políticas de Participação Social da Secretaria-Geral da Presidência da República. De 2003 a 2008, foi responsável pela execução das Políticas de Educação Escolar Indígena da Secretaria de Educação Continuada, Alfabetização e Diversidade/SECAD/MEC, coordenando os seguintes programas: formação de professores; produção de materiais didáticos específicos; apoio à gestão das escolas indígenas; construção de escolas em terras indígenas, dentre outros. Responsável pela articulação do MEC com os Sistemas de Ensino de 24 estados e 198 municípios. Atuou como docente em projetos de formação de professores indígenas entre 1990 e 2003, orientando a produção de materiais didáticos, a construção de currículos e a realização de pesquisas com o objetivo de produzir materiais didáticos específicos e em línguas indígenas. Trabalha atualmente na Assessoria da Secretaria de Estado da Educação de Minas Gerais." A última atualização do CV foi em 04/08/2016 (http:// lattes.cnpq.br/6005573667379491 - acessado em 07/09/2016). 
presença indígena na história do Brasil, como base para revisão do sistema de preconceitos vigente até o presente, ao inserir a presença indígena ao longo de toda a história brasileira. No terceiro livro (Araújo et al., 2006), sobre direitos indígenas, somou-se à coordenadora não indígena, Ana Valéria Araújo - coordenadora executiva da ONG Fundo Brasil de Direitos Humanos, advogada especializada no direito indigenista brasileiro, por longos anos advogando em casos concretos e trabalhando no acompanhamento da formação de estudantes indígenas em direito - à presença de quatro advogados indígenas: dentre eles, Paulo Celso de Oliveira Pankararu, mestre em Direito, ex-bolsista do IFP e assessor do Centro Amazônico de Formação Indígena da Coordenação das Organizações Indígenas da Amazônia Brasileira (Cafi/Coiab), Joênia Batista de Carvalho Wapichana, advogada da organização indígena Conselho Indígena de Roraima e que, naquele ano iniciaria a preparação para o mestrado em Direito com uma bolsa do IFP, Lucia Fernanda Belfort Kaingáng (também mestre em Direito), diretora-executiva do Instituto Indígena Brasileiro para Propriedade Intelectual, Vilmar Moura Guarany (mestrando com bolsa do IFP), advogado da Fundação Nacional do Índio, agência indigenista governamental, e o renomado pesquisador e ativista dos direitos indígenas no plano internacional, o indígena norte-americano S. James Anaya, professor da Faculdade de Direito da Universidade do Arizona. ${ }^{69}$ Cada um deles desenvolveu temas de seu interesse

69 O texto do CV Lattes de Gersem José dos Santos Luciano, cuja última atualização data de 2014, diz o seguinte: "Gersem é índio Baniwa e atualmente Professor Adjunto da Faculdade de Educação e Diretor de Políticas Afirmativas da Universidade Federal do Amazonas (UFAM). É graduado em Filosofia pela Universidade Federal do Amazonas (1995), mestre e doutor em Antropologia Social pela Universidade de Brasília (2006-2011). Recebeu Prêmio Capes de Tese 2012. Como liderança indígena militante, foi dirigente da Federação das Organizações Indígenas do Rio Negro (FOIRN), da Coordenação das Organizações Indígenas da Amazônia Brasileira (COIAB) e Diretor-Presidente do Centro Indígena de Estudos e Pesquisas (CINEP). No campo profissional, foi professor indígena entre 1986 e 1988 na aldeia Carara-Poço, Secretário Municipal de Educação do município de São Gabriel da Cachoeira - AM, no período de 1997 a 1999, Gerente do Projeto Demonstrativo dos Povos Indígenas no Ministério do Meio Ambiente, no período de 2000 a 2004, Perito Local da Embaixada da Alemanha entre 2005 e 2006, Conselheiro do Conselho Nacional de Educação, no período de 2006 a 2008, e Coordenador Geral de Educação Escolar Indígena do Ministério da Educação, no período de 2008 a 2012. Tem experiência na área de Educação, Gestão de Projetos, Desenvolvimento Institucional, com ênfase em Política Educacional, atuando principalmente nos seguintes temas: educação indígena, política indigenista, movimento indígena, desenvolvimento sustentável e povos indígenas." Para uma narrativa autobiográfica de Gersem, ver Luciano-Baniwa (2013, p. 19-29). Para uma dentre outras entrevistas, ver Bergamaschi (2012). Para algum material em vídeo, ver, no âmbito 
e grande importância para os direitos dos povos indígenas. O quarto dos livros da série (Maia, 2006) é um manual de linguística igualmente sem equivalente na produção intelectual brasileira, destinado ao estudo de línguas indígenas e do bilinguismo, escrito, por sugestão da Professora Bruna Franchetto, pelo linguista e hoje professor titular da UFRJ, Marcus Antonio Resende Maia, pesquisador nas áreas de psicolinguística, teoria e análise linguística e línguas indígenas brasileiras.

Já fora da segunda etapa do Trilhas de Conhecimentos e sob o guarda-chuva de outro projeto, conseguiríamos (re)organizar em parceria com a Secad/MEC, ainda que em um quadro de forças bastante distinto em relação ao anterior, dois outros volumes da mesma série. ${ }^{70} \mathrm{O}$ primeiro deles (Garnelo; Pontes, 2012) intitula-se Saúde indígena: uma introdução ao tema, concebido e organizado por Luiza Garnelo e Ana Lucia Pontes (da Escola Politécnica Joaquim Venâncio da Fiocruz), também nesse caso contando com a participação de autores indígenas, fruto do extenso trabalho de formação de agentes indígenas de saúde desenvolvido pelas organizadoras. O sexto e último volume da série (Sousa; Almeida, 2013) denomina-se Gestão territorial em terras indígenas no Brasil, organizado por Cassio Noronha Inglez de Sousa e Fabio Vaz Ribeiro de Almeida, em conjunto com Maira Smith, os três ex-técnicos dos Projetos Demonstrativos dos Povos Indígenas (PDPI) do Ministério do Meio Ambiente, e com Guilherme Martins de Macedo, à época perito técnico da Agência de

da XXVIII RBA, em 2012, https://www.youtube.com/watch?v=Rcd4U4eozbw, e nos quadros da XXIX RBA em 2014, ver https://www.youtube.com/watch?v=FFndFI45gNo. Em http://www. ppgasmn-ufrj.com/joatildeo-pacheco-de-oliveira.html e em http://jpoantropologia.com.br/pt/ encontram-se páginas de João Pacheco de Oliveira e no Museu do Índio, ver http://www.museudoindio.gov.br/. Sobre o FBDH, ver http://www.fundodireitoshumanos.org.br/ (acessados em 07/09/2017). Sobre o Cafi/Coiab, ver Flores (2009). James Anaya foi posteriormente, sucedendo a Rodolfo Stavenhagen, relator das Nações Unidas para os Direitos dos Povos Indígenas, de 2008 a 2014. Esteve e ainda está ligado ao Native Nations Institute da University of University of Arizona (http://igp.arizona.edu/people/james-anaya-jd; http://igp.arizona.edu/) e é Dean e Charles Inglis Thomson Professor da University of Colorado - Boulder (http://lawweb.colorado.edu/ profiles/profile.jsp?id=729). Para sua página pessoal (relativamente desatualizada), ver http:// jamesanaya.org/site/ (acessados em 07/09/2017).

70 Para algumas observações sobre as transformações nas ações governamentais para os povos indígenas e como eles as enfrentaram ao longo desse período, ver Souza Lima (2011) e Ricardo e Ricardo (2011, 2017). Sobre as políticas de educação indígena em particular, ver Paladino e Almeida (2012), Grupioni (2011, 2017) e Souza Lima (2016, 2017). 
Cooperação Técnica Alemã (GIZ) para o Tratado de Cooperação Amazônica no tocante aos assuntos indígenas. ${ }^{71}$

Desde o início do PTC e até recentemente, desenvolvemos um conjunto de ações que podem ser classificadas como advocacy (no sentido que lhe é dado pela cooperação técnica e pela filantropia, isto é, de suporte público e ou recomendação de uma causa ou política) e disseminação de informações, e isso em diversas frentes e por diversas formas, procurando apresentar elementos para se pensar os problemas da formação de indígenas no ensino superior de diversos ângulos - sobretudo aquele da permanência e da inserção profissional futura dos estudantes. Fui a um sem-número de reuniões, seminários, eventos, nos quais estive presente debatendo ações afirmativas para os povos indígenas. No sentido de ter melhores e mais sensíveis instrumentos para esse tipo de atividades, contratamos a elaboração do vídeo (já mencionado) Trilhas de conhecimentos, com base na experiência dos estudantes indígenas do Mato Grosso do Sul e realizado com a participação dos estudantes. Seu material bruto lhes foi enviado para a confecção de filmes futuros. ${ }^{72}$ Com esse mesmo objetivo de divulgação e fomento ao debate, desenvolvemos a partir de 2004 o site do projeto e estabelecemos e alimentamos uma lista de discussão eletrônica no Yahoo!, intitulada Educação Superior de Indígenas, que vem sendo bastante utilizada. Em projetos subsequentes, criamos uma página no Facebook, deno-

71 Sobre a ação da GIZ no tocante às terras e povos indígenas da Amazônia Legal, ver Lima (2003) e Valente $(2007,2010)$. Sobre essa importante carteira de projetos que foi o PDPI, ver http:// www.mma.gov.br/apoio-a-projetos/povos-ind\%C3\%ADgenas (acessado em 07/09/2017), assim como Sousa ( 2007) e Almeida, F. (2010). Cassio Inglez de Sousa, graduado em administração de empresas e mestre em Antropologia pela USP, sob orientação de Aracy Lopes da Silva, já atuara como docente no curso de especialização em gestão em etnodesenvolvimento realizado com a Ufam e hoje é consultor independente. Fabio Vaz Ribeiro de Almeida, historiador, ex-estagiário do Peti, mestre pelo CPDA (Programa de Pós-Graduação em Ciências Sociais em Desenvolvimento, Agricultura e Sociedade, Universidade Federal do Rio de Janeiro /UFRRJ), tendo elaborado sua dissertação de mestrado entre os Ticuna, é hoje coordenador executivo da ONG Instituto Sociedade, População e Natureza (ISPN) (http://www.ispn.org.br/- acessado em 07/09/2017). Maira Smith é bióloga, mestre em Biologia pelo Instituto Nacional de Pesquisas da Amazônia (Inpa) e doutora em Desenvolvimento Sustentável pela UnB e integra a Coordenação Geral de Gestão Ambiental (CGGAM) da Fundação Nacional do Índio. Com Cassio, Fabio, Sondra Wentzel (GIZ) e Maria Helena Ortolan (Ufam), organizamos naquele mesmo período duas coletâneas, utilizando outros recursos, a partir de grupos de trabalho desenvolvidos em reuniões da Reunião Equatorial de Antropologia/Reunião de Antropólogos do Norte e Nordeste (REA/Abanne) (Sousa et al., 2007, 2010).

72 Ver Trilhas de conhecimento (2007). 
minada A Educação Superior de Indígenas e, em função disso, eu mesmo acabei criando um perfil nessa rede social de modo a poder geri-la. ${ }^{73}$

Ainda que o desenho da primeira etapa do PTC não contemplasse pesquisa e produção de conhecimento, conseguimos incluir algumas atividades dessa natureza, como uma bolsa para que Mariana Paladino concluísse sua tese de doutorado (Paladino, 2006) e mais uma coletânea organizada por essa mesma pesquisadora e por Stella García e publicada na Argentina, intitulada Educación escolar indígena: investigaciones antropológicas en Brasil y Argentina (Paladino; García, 2007). ${ }^{74}$

Na segunda etapa do PTC (2007-2009), deixamos o desconfortável papel de "chave do cofre", ou seja, não mais recebemos recursos para fazer doações a outras universidades, papel esse que sempre julgamos inconveniente, por diversas razões, sobretudo pela parte operacional descrita anteriormente. Assim, apesar de mantermos o trabalho de assessoramento aos núcleos, o escritório da Fundação Ford passou a fazer diretamente as doações com recursos da PHEI, agora tendo Aurélio Vianna Jr. à frente das questões indígenas e dos povos tradicionais. ${ }^{75} \mathrm{As}$ novas doações ao Programa Rede de Saberes passariam a ser feitas desse modo. Ao Laced coube, portanto, manter um conjunto de ações que contribuíssem para

73 Ver em http://br.groups.yahoo.com/group/superiorindigena/ (acessado em 07/09/2017). As listas eletrônicas foram um instrumento de grande importância antes do advento das redes sociais, especialmente do Facebook. Hoje, a página nessa rede social passou a se chamar publicamente LACED/Museu Nacional-UFRJ mesmo que seu endereço ainda seja: https://www.facebook.com/AEducacaoSuperiorIndigena/ (acessado em 07/09/2017).

74 Mariana Paladino é, segundo texto por ela informado: “Licenciada em Antropologia pela Universidade Nacional de La Plata, Argentina (1998). Mestre em Antropologia Social (2001) e Doutora em Antropologia (2006) pelo Programa de Pós-Graduação em Antropologia Social (PPGAS) da Universidade Federal do Rio de Janeiro. Atualmente é Professora Adjunta Dedicação Exclusiva na Faculdade de Educação da Universidade Federal Fluminense, atuando na área de Antropologia e Educação. Integra o Grupo de Pesquisa Antropologia e Educação e o Laboratório de Educação e Patrimônio Cultural da UFF. É também pesquisadora associada ao Laboratório de Pesquisas em Etnicidade, Cultura e Desenvolvimento (LACED), Departamento de Antropologia, Museu Nacional. Foi bolsista de Pós-doutorado Junior do CNPq (2007-2009). Tem experiência na área de Etnologia e Antropologia da Educação, com ênfase na educação escolar indígena, atuando principalmente nos seguintes temas: educação, interculturalidade, ações afirmativas, políticas indigenistas e relações interétnicas" (http://www.laboep.uff.br/quem-somos/professores/22-mariana-paladino - acessado em 07/09/2017). Das pessoas formadas sob minha orientação, Mariana Paladino foi sempre a que teve a discussão sobre educação escolar indígena como alvo principal de seus investimentos, acumulando atualmente muitos projetos e publicações.

75 As doações com recursos da PHEI feitas para negros estavam sob a responsabilidade de Denise Dora, então PO de Direitos Humanos no escritório da FF no Brasil. A esse respeito, ver Vianna Jr. (2015). 
o preparo das universidades públicas e privadas no Brasil visando à melhoria de sua capacidade de promoção de políticas institucionais para o acesso, a permanência e o sucesso de indígenas em cursos de nível superior, por meio do treinamento de integrantes de seus quadros docentes e técnico-administrativos.

Deveríamos, ainda, colaborar para que as organizações indígenas se equipassem para o diálogo concernente às políticas governamentais e institucionais para o ensino superior de indígenas, de modo que se tornassem aptas a debater esses temas, com especial ênfase no reconhecimento dos conhecimentos tradicionais indígenas e em seu valor para a gestão de territórios de suas coletividades. Era ainda parte de nossas atribuições produzir reflexões críticas sobre o próprio PTC e de outras ações para o ensino superior de indígenas no Brasil, analisando e debatendo a conjuntura política nacional e as ações pertinentes para lhe fazer frente, visando colaborar para a produção de conhecimentos sobre as ações afirmativas para povos indígenas.

Para tanto, participantes da equipe produziram dissertações de mestrado (Almeida, N., 2008, 2013; Paulino, 2008, 2013, 2016) e uma tese de doutorado (Barroso-Hoffman, 2009, já mencionada na nota 38, cuja publicação integrou o projeto). Preparamos também três livros sobre a conjuntura e a experiência por nós levada a cabo, dos quais dois foram publicados (Souza Lima; Barroso, 2013a; Souza Lima; Paladino, 2012a) e um ainda se encontra pendente (Souza Lima; Barroso, 2017).

Ainda nessa segunda etapa (2007-2009), o PTC contribuiu para a estruturação e passou a atuar como assessor do Centro Indígena de Estudos e Pesquisas (Cinep), com o qual o Laced manteve uma parceria de trabalho. Pensado por Gersem Luciano Baniwa e outros indígenas para ser uma instituição de formação política indígena e produtora de intelectuais, o Cinep organizou cursos de formação política para lideranças indígenas que, registrados, nos permitiram produzir um conjunto de videoaulas, editadas e disponibilizadas on-line com recursos dos projetos subsequentes, para as quais produzimos um caderno de exercícios para trabalho à distância. O Cinep organizou publicações de trabalhos de pesquisadores indígenas e um primeiro Congresso Nacional de Estudantes Indígenas, realizado em 2009, em Brasília, em parceria com o PTC.76

76 Ver em http://laced.etc.br/site/acervo/video-aulas/o-estado-e-os-povos-indigenas-no-brasil/ (acessado em 07/09/2017). 
Com o objetivo de transferir os conhecimentos que ajudáramos a produzir (em especial os contidos nos livros paradidáticos) e de formar os indígenas e não indígenas atuantes em postos de gestão na área de educação indígena de certa forma retomando, portanto, as ideias que nos haviam motivado em 1999-2002 na implementação dos cursos de especialização - desenvolvemos um curso de aperfeiçoamento à distância, contando, para tanto, com os trabalhos de técnicos em educação à distância (EAD) da Fundação Getúlio Vargas Online (FGVOnline). Toda a preparação desse material nos ensinou muito não só sobre o EAD, mas também sobre a carga de preconceitos entranhados em profissionais altamente qualificados para algumas das atividades que precisávamos desenvolver. Acertamos ainda com André Lázaro que a Secad/MEC pagaria as turmas-piloto, para tanto descentralizando recursos para a UFRJ, numa operação rotineira à época, como forma de viabilizar inúmeras atividades para as quais o MEC não tinha a estrutura operacional necessária. Susana Guimarães, linguista e figura essencial na CGEEI/Secad/MEC, que assegurou a continuidade de trabalhos entre gestões, preparou o material referente à educação escolar indígena, em seu sentido conceitual e normativo, e participou conosco da seleção de candidatos para as quatro turmas de 30 alunos, num total de 120.

Veríamos, no entanto, o quanto essa decisão poderia se tornar complicada pela ação dos procuradores da Advocacia Geral da União (AGU) na UFRJ, que, após terem aceito a dispensa de licitação para a contratação da FGVOnline, com base na existência de notória experiência e de um convênio entre as duas instituições, voltaram atrás, afirmando que a escolha da referida instituição seria fruto de favorecimento indevido. Foi somente após a intervenção do reitor da UFRJ, à época, o Professor Aloisio Teixeira, que conseguimos, após alguns meses de idas e vindas, resolver o problema e viabilizar que a FGVOnline, que já havia preparado tecnicamente o curso, fosse também a base de sua execução.

Houve um hiato durante o qual pouco aconteceu no cenário governamental no sentido de fomento a novas ações no tocante à pauta da educação escolar indígena em geral. Esse hiato corresponde aos primeiros anos de governo de Dilma Rousseff e à reestruturação organizacional do MEC, no início de 2011, a partir da qual a Secretaria de Educação Especial foi extinta, e suas atribuições repassadas à Secad, que passaria a Secadi, sendo o "i” de inclusão, tarefa que seria privilegiada a partir de então. 
Somente com a entrada da Professora Macaé Evaristo como secretária (2013-2014), a interlocução que nunca perdemos com a CGEEI foi retomada no âmbito da Secadi, o que foi possível pelo retorno do investimento em ações de educação para a diversidade. ${ }^{77}$ Assim, em 2013, o curso de aperfeiçoamento à distância veio a ser incluído no catálogo temático da Secadi na Rede Nacional de Formação Continuada de Professores na Educação Básica (Renafor), tornando-se de fato o protótipo de um tipo de curso para qualificação do magistério da educação escolar indígena que poderia vir a ser executado por outras universidades, ganhando com isso o título de Curso de Educação Escolar Indígena: Subsídios para a Gestão Etnoterritorializada.

Ele foi redimensionado para um curso de aperfeiçoamento de 180 horas integralmente à distância, destinado a gestores e docentes de educação escolar indígena de todo o território brasileiro, tendo sido oferecido no segundo semestre de 2014, a partir da área de educação à distância da UFRJ, sob a minha coordenação e a de Marcos Moreira Paulino. Foram oferecidas 240 vagas, que foram integralmente preenchidas, ainda que apenas 72 cursistas o tenham concluído. Tínhamos a intenção de oportunamente produzi-lo como um mestrado profissional e oferecê-lo possivelmente em rede. Nesse mesmo ano e período, com a coordenação pedagógica de Mariana Paladino e Kelly Russo, ambas integrantes do Laced e participantes de projetos subsequentes ao PTC, foi desenvolvido e oferecido através da Renafor um curso destinado à rede escolar do estado do Rio de Janeiro, intitulado Cultura e História dos Povos Indígenas, com subsídios ao cumprimento da lei $n^{\circ} 11.645$, de caráter semipresencial. ${ }^{78}$

A colaboração com a Secadi/MEC, tendo à frente as Professoras Rita (Potiguara) Gomes Nascimento (como coordenadora da CGEEI) e Macaé Evaristo (como secretária), nesse período, ainda permitiu a realização de um seminário de avaliação do que havia sido feito em uma década de trabalhos de diversos segmentos engajados nas ações afirmativas para povos indígenas. O seminário intitulou-se Educação Superior de Indígenas: Balanços de uma Década e

77 Macaé Evaristo é atualmente secretária de Estado de Educação de Minas Gerais. Para um CV abreviado, ver https://www.educacao.mg.gov.br/ajuda/page/16910-curriculo-de-macae-maria-evaristo-dos-santos (acessado em 07/09/2017).

78 Para acesso a parte do material desse curso, ver: http://laced.etc.br/site/atividades/cursos/ curso-de-gestao-etno-territorializada-da-educacao-escolar-indigena/ (acessado em 07/09/2017). 
Subsídios para o Futuro e foi realizado em Brasília, de 25 a 26 de novembro de 2013. Durante o seminário discutiu-se, dentre muitos outros assuntos, algumas dificuldades na implantação, junto aos indígenas, do Programa Bolsa Permanência, já anteriormente referido. Ele gerou um relatório conclusivo que traz um balanço à luz de muitas vozes e coloca questões importantes para desenvolvimentos futuros, tendo sido distribuído a todos os participantes e a interessados e publicado em Souza Lima (2016). Da mesma forma, com base no material filmado das mesas do seminário, divulgaríamos o vídeo mencionado na nota 5 .

Ainda nesse ano de 2013, realizamos nos dias 12 e 13 de novembro, em Brasília, em parceria com a ONG Instituto Internacional de Educação do Brasil, na qual o Professor Henyo Trindade Barreto Filho atuava como coordenador de programa, e com a Coordenação Geral de Gestão Ambiental da Funai, a oficina Desafios de Implementação da Política Nacional de Gestão Territorial e Ambiental de Terras Indígenas/PNGATI: Processos Formativos em Gestão Territorial no Brasil, que também gerou um relatório, ainda por ser divulgado, e um vídeo. ${ }^{79}$ Com esse trabalho, julgamos difundir os conteúdos básicos de uma formação genérica a que idealmente todos os indígenas que estivessem em universidades deveriam ter acesso, não importando o curso em que estivessem inscritos, já que espelham os direitos culturalmente diferenciados assegurados na Constituição de 1988 e, ao mesmo tempo, dão conta de modo relativamente crítico das políticas de governo pensadas para eles (e não necessariamente com eles). Publicamos, também, outros materiais de cunho didático em livro e em vídeo, dentre eles uma série que chamamos de "Videobiografias Indígenas", todos disponíveis na página do Laced. ${ }^{80}$ Há, portanto, algum material ainda a ser finalizado por razões estritamente pessoais, o que acho que acabou por ser interessante ao permitir manter senão aquecida, ao menos sinalizada uma discussão que está longe de se encerrar.

79 Também disponível via o site do Laced. Além de Henyo Barreto Filho, amigo e colaborador desde sua passagem pelo Peti como estagiário, contamos ainda com a interlocução de Andreia Bavaresco (IEB), Cássio Noronha Inglez de Sousa (Comtexto Consultoria), Cloude Correia (IEB), Fábio Vaz Ribeiro de Almeida (ISPN), Guilherme Martins de Macedo (GIZ), Marcela Menezes (IEB) e João Guilherme Nunes Cruz (CGGAM-Funai) na elaboração e realização desse seminário.

80 Ver De Paula e Vianna (2011), Paladino e Almeida (2012), Collet, Paladino e Russo (2014) e Oliveira (2014). Para a série de videobiografias indígenas, ver http://laced.etc.br/site/acervo/ videobiografias-indigenas/. 


\section{Algumas observações finais}

Em 2004, quando realizamos o seminário Desafios para a Educação Superior dos Povos Indígenas no Brasil, Luis Otávio Pinheiro da Cunha, falando desde a Funai, estimou em 1300 o número de estudantes indígenas no ensino superior, frisando estarem esses majoritariamente inscritos em instituições privadas (Souza Lima; Barroso-Hoffmann, 2007, p. 85). Em dados do censo da educação superior do Instituto de Estudos e Pesquisas Educacionais Anísio Teixeira (Inep) para 2015, eram então 32.147 indígenas matriculados, sendo 9810 em instituições públicas (7392 em instituições federais, 2268 em instituições estaduais, 150 em instituições municipais) e 22.337 em instituições privadas (Instituto de Estudos e Pesquisas Educacionais Anísio Teixeira, 2016). Problemas de notificação à parte, os números de certo modo espelham o padrão de expansão mais geral de crescimento das matrículas ao longo dos anos: se o ensino público federal cresceu, cresceu ainda mais substancialmente o ensino privado.

Por mais que esses dados sejam passíveis de crítica (sempre o são), eles são indicativos das grandes transformações na vida social dos povos indígenas nas mais variadas regiões do país. E essa observação não é de cunho valorativo, nem tampouco absoluto. Trata-se de uma constatação. $O$ fato é que as políticas de governo chegaram às aldeias como nunca antes. Do mesmo modo, e de maneira bastante distinta daquela dos grandes processos de expansão nos quais impera a construção de grandes obras de infraestrutura, como as típicas dos anos 1970-1980 (também presentes, mas não tendo sido o centro do desenvolvimentismo dos últimos anos), a expansão do agronegócio sobre as terras indígenas se fez inapelável. Apesar de a situação fundiária indígena ter sido definida em parte considerável da Amazônia, em muitas regiões do país, as terras indígenas estão avassaladas e a violência sob muitas formas é parte de seu cotidiano. Um tempo em que as roças foram deixadas pelo miojo e em que o diabetes cresceu pelo Brasil indígena afora. Foi num cenário de desenvolvimentismo facultado por um ciclo expansivo da exportação de commodities, durante os governos petistas, nos quais as políticas para a diversidade foram de muito difícil desenvolvimento, que se generalizaram para o bem ou para o mal, também para os indígenas, as políticas de combate à pobreza e de universalização da educação, inclusive de acesso à universidade, com a implantação das 
ações afirmativas, sobretudo pela via das cotas, mas também do Prouni - Programa Universidade para Todos. ${ }^{81}$

No livro de sua tese de doutorado, sobre a educação entre os povos do Alto Rio Negro, Gersem Luciano (Luciano-Baniwa, 2013) destaca como a educação se tornou um objeto de desejo e interesse, situação que cremos ser muito mais geral e conectada às grandes transformações nos modos de vida mais próximos aos de campesinatos indígenas. ${ }^{82}$ As cidades e a escola como via de acesso a posições nesse mundo hegemonizado pelo urbano assumiram e parecem continuar assumindo uma importância significativa na vida de muitos povos indígenas. $\mathrm{O}$ assalariamento é uma realidade para muitos, tanto quanto a ausência das muito reivindicadas e prometidas políticas para a sustentabilidade.

Foi tendo em vista parte dessas transformações, muitas das quais se acirraram nesses anos, tanto quanto o fato de que a terra é um valor entre indígenas para além das possibilidades de sua exploração econômica, que concebemos as ações do Trilhas de Conhecimentos e de seus desdobramentos. De meu ponto de vista individual, eu acreditava e ainda acredito que estávamos contribuindo, dentro daquilo que os próprios indígenas solicitavam, para avançar na quebra do padrão tutelar de governo dos povos indígenas, sobre o qual meu trabalho como pesquisador foi centrado. Procuramos nos pautar pelo diálogo com os próprios indígenas e, depois, com gestores federais da área de educação, bem como com docentes universitários - em larga medida sobretudo com a rede de colegas antropólogos com quem mantemos interlocução, e por isso nada do que eu particularmente fiz pode ser desentranhado da minha participação na Associação Brasileira de Antropologia em diferentes posições, ainda que as escolhas pelas atividades (quando foi possível fazê-las) numa e noutra direção tenham razões distintas.

Nossos esforços não foram os únicos. ${ }^{83}$ Nem foram pensados para ocupar uma posição hegemônica. Procuramos menos que falar (somente) sobre, agir

81 O Prouni “é o programa do Ministério da Educação que concede bolsas de estudo integrais e parciais de 50\% em instituições privadas de educação superior, em cursos de graduação e sequenciais de formação específica, a estudantes brasileiros sem diploma de nível superior". Ver em http://siteprouni.mec.gov.br/ (acessado em 07/09/2017).

82 Ver também Amado (2016).

83 Para grupos de universitários trabalhando as relações entre universidades e comunidades indígenas, ver Russo (2016). 
para as ações afirmativas para os povos indígenas. Sem dúvida, isso abre mais espaços a críticas, o que é saudável e produtivo. Mas também gera possibilidades de apagamento e apropriação não declarada. Alguns diálogos foram fundamentais, tendo sido mencionados ao longo do texto. Mas haveria muito o que indagar, por exemplo, quando sabemos que hoje se estimam em cerca de 5 mil os estudantes de comunidades quilombolas, ao ponto de, segundo comunicação pessoal de Aurélio Vianna Jr., a Coordenação Nacional de Articulação das Comunidades Rurais Negras Quilombolas (Conaq), vir se organizando para fazer frente a essa demanda e, de modo análogo, muitas universidades e institutos federais de tecnologia, sendo que, em larga medida, os primeiros caminhos nessa direção foram trilhados pelos e para os indígenas.

Considero, pois, que realizamos uma leitura do cenário mais geral do período pós-constitucional, à luz da investigação concernente à relação sobre as formas de movimentação política dos indígenas, sobre as ações de Estado nas políticas indigenistas e, de modo mais geral, nas políticas indigenistas. Afinal, estive todo o tempo envolvido com pesquisas de outros colegas e estudantes sobre questões muito distintas das indígenas, mas percebendo confluências e refrações. E, nesses termos, de certo modo nossas atividades teriam sido muito distintas se fôssemos pesquisadores ligados ao estudo da educação superior, preocupados em reformá-la per se, focados na obsedante e turva ideia de educação intercultural. No entanto, como Vianna Jr. bem sinaliza em seu texto aqui citado, as razões de nossa escolha pela FF foram outras, ainda que isto tenha nos custado sermos os "estranhos no ninho" dos Pathways latino-americanos e que tenhamos tido de explicar que, no caso brasileiro, a ação federal e o engajamento de movimentos indígenas eram itens essenciais. Para casos como o peruano, falar em movimentos indígenas significava trazer de volta a sombra da guerrilha.

Para desenvolver tais ações, foi preciso aprender a trabalhar em múltiplas escalas, como a internacional, por força do financiamento da FF (ou por conta da intensa importação dos contextos latino-americanos de ideais da interculturalidade no ensino superior). Mas privilegiamos o corte nacional, no qual as ações de governo são usualmente concebidas, até mesmo na tentativa de sinalizar como elas podem ser generalizantes, ainda que dentro das especificidades das situações indígenas. Por conta do acompanhamento dos núcleos, precisávamos entender o que se passava na escala regional, na qual se situam as instituições de educação superior e algumas das formas de organização indígenas 
com que lidamos. Por fim, tivemos de lidar com as características singulares e "locais" de muitas instituições, pois era ao âmbito institucional que boa parte de nosso trabalho se dirigia.

Parte substancial de nossas atividades foi estabelecer ou reforçar redes que não existiam, não necessariamente reivindicando uma posição central ou dominante. Do mesmo modo, procuramos reunir e produzir conhecimentos, divulgando-os, e preparar pesquisadores. Para tanto, produzimos seminários (também e sobretudo momentos de articulação política inclusive), vídeos, livros, teses e dissertações. Se isso é parte corriqueira de nossas atividades de trabalho como docentes em universidades federais, creio que diversas outras estavam fora desses eixos mais usuais e acabam sendo, na vida acadêmica, subsumidas e sub-representadas na ideia de extensão. Todo o difícil e penoso trabalho de indução à demanda e depois de acompanhamento dos núcleos, sendo vistos como "donos do dinheiro", "chave do cofre" (o que não fomos de fato em momento algum, ainda que nossas possibilidades de escolha tenham sido grandes e respeitadas, muitas vezes à custa de muita discussão, pela FF) e, ainda por cima, "do Museu Nacional", com toda a carga ambígua que esse pertencimento projeta, com as clivagens que comporta e as usuais manipulações a partir desta posição, implicaram muita energia e trouxeram muito desgaste.

Essa dimensão do trabalho nos leva à intensa atividade de gestão que, sem dúvida, se beneficiou do fato de minha vida profissional ter sido marcada pelo trabalho em equipe e pela função nem sempre simpática ou agradável de "gestor" em muitas dessas atividades. Se criar as condições sociais e institucionais dos trabalhos em que estive envolvido foi uma atividade comum em minha trajetória, esse tipo de intervenção me colocou desafios e a necessidade de um aprendizado que me retirou quaisquer fantasias - se algum dia as tive - sobre o "enorme poder" que certos gestores governamentais poderiam ter. Mais do que nunca, e negociando ações em planos muito diversos, pude ver como a malha da administração pública no Brasil é complexa e como a legislação fiscal e tributária produz os desvios ou inviabiliza a vida administrativa cotidiana.

Por outro lado, talvez exatamente a minha formação, inclusive no plano profissional, dentro do Museu Nacional (e não meramente no PPGAS), e o conhecimento de sua história, tenham me levado a perceber muito do que se poderia recobrir com a categoria ampla e imprecisa de "ação política" como 
parte do meu fazer e de minhas obrigações..$^{84}$ Eu sempre penso que, à similitude de outras instituições científicas existentes no Brasil, independentemente do fato de terem ou não cursos de graduação (além das funções de guarda, curadoria e exposição de coleções científicas), o Museu Nacional guarda a preocupação de intervir na vida pública a partir do ponto de vista da ciência.

Para esse trabalho, a interlocução com alguns companheiros de trajetória foi essencial. Dentro do projeto, foi indiscutivelmente com Maria Macedo Barroso com quem mais trabalhei e refleti em conjunto. Com Aurélio Vianna Jr., portador de amplo conhecimento sobre as realidades indígenas, quilombolas e dos povos tradicionais, pude aos poucos ir aprendendo sobre as múltiplas dimensões, até então para nós nada transparentes, dos bastidores da FF (em especial da PHEI). Sem sua mediação e capacidade de tradução para todos os mundos envolvidos nas ações sob sua responsabilidade, teria sido impossível levar adiante nossas atividades (para dizer o mínimo). Afinal, como grantee da FF desde 1985, vi muitas FFs ao longo do tempo, o que nem todos os POs podem observar no período de trabalho em geral restrito a dois contratos de três anos cada. Foi preciso aprender a ver a mudança, por força das atribuições que durante esse período desempenhamos. Tampouco poderíamos prescindir dos debates com os integrantes do comitê assessor, em especial com Fulvia Rosemberg, Gersem Luciano Baniwa, Maninha Xukuru e Beatriz Heredia, assim como, sem a interlocução fundamental com o amigo Antonio Brand, não nos teria sido possível realizar o pouco que conseguimos, diante do tamanho e da complexidade das tarefas pendentes.

84 Entrei como aluno do PPGAS/Museu Nacional em março de 1980, mas já em 1985, por conta do Peti, eu trabalhava diariamente no Museu Nacional, embora ainda ministrasse aulas em universidades particulares. Em 1986, deixei todas as atividades didáticas e centrei-me na pesquisa (que sempre foi meu maior objetivo). Em julho de 1987, obtive, por indicação de Beatriz Heredia, um contrato de técnico em antropologia na UFRJ, que depois seria transferido para o Museu Nacional. Em 1988, fiz concurso para professor assistente de Etnologia juntamente com Berta Ribeiro, que ficaria em mais que merecido e óbvio primeiro lugar, e com Bruna Franchetto que, naquele mesmo ano, entrou para o Departamento de Linguística da Faculdade de Letras/ UFRJ, tendo sido posteriormente transferida para o Setor de Linguística do Museu Nacional. Em dezembro de 1989, pela eventualidade de vacâncias por morte e aposentadoria no Setor de Etnologia, fui contratado como docente. Para um breve relato institucional da ação do Museu Nacional na educação científica de modo mais abrangente e para as ações de personagens históricos de grande importância na vida pública brasileira, como Edgard Roquete-Pinto, ver, por exemplo: https://saemuseunacional.wordpress.com/a-sae/ (acessado em 07/09/2017). Para um denso trabalho sobre tal dimensão do papel do Museu Nacional "na formação [científica] das almas" (para tomar emprestada a expressão de José Murilo de Carvalho), ver Sily (2012). 
Hoje seria de todo impossível realizar a maior parte das atividades que desenvolvemos, em especial as de incentivo à demanda, mas não só. Também muitas das ações corriqueiras que levamos a cabo, em projetos posteriores, seriam no mínimo retardadas ou obstaculizadas (passamos por isso com um projeto nesse momento) pelo simples fato de que a judicialização e a criminalização das ações no âmbito também das universidades e das fundações universitárias chegaram a um tal ponto que os setores jurídicos das fundações e os procuradores da AGU lotados nas universidades hesitam ou simplesmente travam os mais elementares processos. Muitas responsabilidades que os pesquisadores - os mais interessados em não haver desvios ou gastos indevidos - não deveriam desempenhar lhes são transferidas. Estamos definitivamente em outra conjuntura, não apenas da vida brasileira, mas também da história da Fundação Ford e do cenário estadunidense em que ela se enraíza e sustenta. Há muito por ser dito e ser feito à luz desse novo e desalentador momento.

\section{Referências}

AGUILERA URQUIZA, A. H.; NASCIMENTO, A. C. Rede de saberes: políticas de ação afirmativa no ensino superior para indígenas no Mato Grosso do Sul. Rio de Janeiro: Flacso/GEA: UERJ/LPP, 2013. (Coleção Estudos Afirmativos, v. 1).

AGUILERA URQUIZA, A. H. et al. Rede de saberes: o cotidiano de uma experiência de interculturalidade na universidade. In: SOUZA LIMA, A. C. de; BARROSO, M. M. (Org.). O Projeto Trilhas de Conhecimentos e o ensino superior de indígenas no Brasil: uma experiência de fomento a ações afirmativas. Rio de Janeiro: E-papers, 2017. No prelo.

AINDA há racismo no Brasil, diz Fernando Henrique Cardoso. Folha de S. Paulo, 21 nov. 2002. Disponível em: <http://wwwl.folha.uol.com.br/folha/brasil/ult96u42675. shtml>. Acesso em: 7 set. 2017.

ALMEIDA, A. W. B. de. Os quilombos e as novas etnias. In: O'DWYER, E. C. (Org.). Quilombos: identidade étnica e territorialidade. Rio de Janeiro: Editora FGV: ABA, 2002. p. 43-81.

ALMEIDA, F. V. R. de. O índio sabe, o índio faz: os dilemas da participação indígena nas políticas públicas. In: SOUSA, C. N. I. de et al. (Org.). Povos indígenas: projetos e desenvolvimento, II. Brasília: Paralelo 15; Rio de Janeiro: Laced, 2010. p. 177-185. Disponível em: <http://laced.etc.br/site/arquivos/11-Povos-II.pdf>. Acesso em: 7 set. 2017. 
ALMEIDA, N. P. Diversidade na universidade: o BID e as políticas educacionais de inclusão étnico-racial no Brasil. 2008. Dissertação (Mestrado em Antropologia Social)Museu Nacional, Universidade Federal do Rio de Janeiro, Rio de Janeiro, 2008.

ALMEIDA, N. P. O Programa Diversidade na Universidade e as ações afirmativas para o acesso de negros e indígenas ao ensino superior. In: SOUZA LIMA, A. C. de; BARROSO, M. M. (Org.). Povos indígenas e universidade no Brasil: contextos e perspectivas, 2004-2008. Rio de Janeiro: E-papers, 2013. p. 163-194. (Abrindo Trilhas, 2). Disponível em: <http://laced.etc.br/site/pdfs/LivroPovosIndigenas.pdf>. Acesso em: 7 set. 2017.

ALMEIDA, N. P. Entre a tutela e a autonomia: a atuação da Funai na promoção do acesso e da permanência de indígenas no ensino superior. 2014. Tese (Doutorado em Antropologia Social)-Museu Nacional, Universidade Federal do Rio de Janeiro, Rio de Janeiro, 2014.

ALMEIDA FILHO, N. Universidade nova: textos críticos e esperançosos. Salvador: EdUFBA, 2007.

AMADO, S. E. O ensino superior para os povos indígenas de Mato Grosso do Sul: desafios, superação e profissionalização. 2016. Dissertação (Mestrado em Antropologia Social)Museu Nacional, Universidade Federal do Rio de Janeiro, Rio de Janeiro, 2016.

AMARAL, W. R. do. As trajetórias dos estudantes indígenas nas universidades estaduais do Paraná: sujeitos e pertencimentos. 2010. Tese (Doutorado em Educação)-Setor de Educação, Universidade Federal do Paraná, Curitiba, 2010.

AMARAL, W. R. do; FRAGA, L.; RODRIGUES, I. C. Universidade para indígenas: a experiência do Paraná. Rio de Janeiro: Flacso/GEA; UERJ/LPP, 2016. (Coleção Estudos Afirmativos, v. 8).

ARAÚJO, A. V. et al. Povos indígenas e a lei dos "brancos": o direito à diferença. Brasília: Ministério da Educação, Secretaria de Educação Continuada, Alfabetização e Diversidade; Laced/Museu Nacional, 2006. (Série Vias dos Saberes, 3; Coleção Educação Para Todos, 14). Disponível em: <http://laced.etc.br/site/Trilhas/livros/arquivos/ ColET14_ViasO3WEB.pdf>. Acesso em: 7 set. 2017.

BANIWA, G. Lei das Cotas e os povos indígenas: mais um desafio para a diversidade. Cadernos de Pensamento Crítico Latino-Americano, Rio de Janeiro, v. 35, p. 18-21, jan. 2013.

BARNES, E. V. Do Diversidade ao Prolind: reflexões sobre as políticas públicas do MEC para a formação superior e povos indígenas. In: SOUSA, C. N. I. de et al. (Org.). Povos indígenas: projetos e desenvolvimento, II. Brasília: Paralelo 15; Rio de Janeiro: Laced, 2010. p. 63-73. Disponível em: <http://laced.etc.br/site/arquivos/05-Povos-II.pdf>. Acesso em: 7 set. 2017. 
BARROSO, M. M. Da formação de professores à presença indígenas nos cursos universais: o "Trilhas" e a superação da tutela pelo ensino superior. In: SOUZA LIMA, A. C. de; BARROSO, M. M. (Org.). Povos indígenas e universidade no Brasil: contextos e perspectivas, 2004-2008. Rio de Janeiro: E-papers, 2013. p. 79-107. (Abrindo Trilhas, 2). Disponível em: <http://laced.etc.br/site/pdfs/LivroPovosIndigenas.pdf >. Acesso em: 7 set. 2017.

BARROSO-HOFFMANN, M. Fronteiras étnicas, fronteiras de estado e imaginação da nação: um estudo sobre a cooperação internacional norueguesa junto aos povos indígenas. Rio de Janeiro: E-papers, 2009.

BASES para uma nova Política Indigenista. Produção, direção e edição: Bruno Pacheco de Oliveira. Rio de Janeiro: Museu Nacional, 2000. Vídeo documentário. Disponível em: <https://www.youtube.com/watch?v=jqcdgtTAOH8>. Acesso em: 7 set. 2017.

BELTRÃO, J. F. Formação jurídica e povos indígenas: desafios para uma educação superior. Relatório do seminário realizado em Belém, Pará, 21 a 23 de março de 2007. In: SOUZA LIMA, A. C. de; BARROSO, M. M. (Org.). O Projeto Trilhas de Conhecimentos e o ensino superior de indígenas no Brasil: uma experiência de fomento a ações afirmativas. Rio de Janeiro: E-papers, 2017. No prelo.

BERGAMASCHI, M. A. Entrevista: Gersem José dos Santos Luciano - Gersem Baniwa. Pelotas (RS), 15 de maio de 2012, durante o II Fórum Internacional da Temática Indígena. História Hoje, São Paulo, v. 1, n. 2, p. 127-148, 2012. Disponível em: <https://rhhj. anpuh.org/RHHJ/article/view/44/34>. Acesso em: 7 set. 2017.

BEVILAQUA, C. B. Entre o previsível e o contingente: etnografia do processo de decisão sobre uma política de ação afirmativa. Revista de Antropologia, São Paulo, v. 48, n. 1, p. 167-225, jan./jun. 2005. Disponível em: <http://www.scielo.br/pdf/ra/v48nl/ a05v48n1.pdf>. Acesso em: 7 set. 2017.

BONDIM, R. G. Acesso e permanência de índios em cursos de nível superior. In: RICARDO, B.; RICARDO, F. (Ed.). Povos indigenas no Brasil: 2001-2005. São Paulo: Instituto Socioambiental, 2006. p. 161-162.

BONDIM, R. G. Propostas feitas pela SESU/MEC no seminário Desafios para uma Educação Superior para os Povos Indígenas no Brasil: políticas públicas de Ação Afirmativa e Direitos Culturais Diferenciados. In: SOUZA LIMA, A. C. de; BARROSO-HOFFMAN, M. (Org.). Desafios para uma educação superior para os povos indígenas no Brasil: políticas públicas de ação afirmativa e direitos culturais diferenciados. Publicação do material referente ao seminário realizado em agosto de 2004 . Rio de Janeiro: Museu Nacional/UFRJ/Laced, 2007. p. 87-90. Relatório técnico publicado. Disponível em: <http://www.trilhasdeconhecimentos.etc.br/livros/arquivos/Desafios.pdf $>$. Acesso em: 7 set. 2017. 
BONDIM, R. G. Educação superior de indígenas: de que estamos falando?. In: SOUZA LIMA, A. C. de; BARROSO, M. M. (Org.). Povos indígenas e universidade no Brasil: contextos e perspectivas, 2004-2008. Rio de Janeiro: E-papers, 2013. p. 119-132. (Abrindo Trilhas, 2). Disponível em: <http://laced.etc.br/site/pdfs/LivroPovosIndigenas.pdf>. Acesso em: 7 set. 2017.

BRAGA, M. L. de S.; SILVEIRA, M. H. V. da (Org.). O Programa Diversidade na Universidade e a construção de uma política educacional anti-racista. Brasília: Secretaria de Educação Continuada, Alfabetização e Diversidade: Unesco, 2007. (Coleção Educação Para Todos, 29).

BRANDÃO, A. A. (Org.). Cotas raciais no Brasil: a primeira avaliação. Rio de Janeiro: DP\&A: LPP/UERJ, 2007.

BRASIL. Presidência da República. Casa Civil. Subchefia para Assuntos Jurídicos. Lei $n^{\circ} 10.558$, de 13 de novembro de 2002. Cria o Programa Diversidade na Universidade, $\mathrm{e}$ dá outras providências. Brasília, 2002. Disponível em: <http://www.planalto.gov.br/ ccivil_03/leis/2002/L10558.htm>. Acesso em: 7 set. 2017.

BRASIL. Ministério da Educação. Secretaria de Educação Superior. Edital de convocação $n^{\circ}$ 5, de 29 de junho de 2005. Diário Oficial da União, Brasília, n. 124, 30 jun. 2005. Seção 3, p. 49-50. Disponível em: <http://pesquisa.in.gov.br/imprensa/jsp/ visualiza/index.jsp?jornal=3\&pagina=49\&data=30/06/2005> . Acesso em: 7 set. 2017.

BRASIL. Ministério da Educação. Secretaria de Educação Continuada, Alfabetização e Diversidade. Edital de convocação $n^{\circ} 3$, de 24 de junho de 2008. Diário Oficial da União, Brasília, n. 121, 26 jun. 2008. Seção 3, p. 39-41. Disponível em: <http:// pesquisa.in.gov.br/imprensa/jsp/visualiza/index.jsp?jornal=3\&pagina $=39 \& d$ ata=26/06/2008>. Acesso em: 7 set. 2017.

BRASIL. Ministério da Educação. Secretaria de Educação Continuada, Alfabetização e Diversidade. Edital de convocação n ${ }^{\circ}$ 8, de 27 de abril de 2009. Diário Oficial da União, Brasília, n. 79, 28 abr. 2009. Seção 3, p. 47-49. Disponível em: <http:// pesquisa.in.gov.br/imprensa/jsp/visualiza/index.jsp?jornal=3\&pagina $=47 \& d$ ata=28/04/2009>. Acesso em: 7 set. 2017.

BRASIL. Ministério da Educação. Portaria n 389, de 9 de maio de 2013. Cria o Programa de Bolsa Permanência e dá outras providências. Diário Oficial da União, Brasília, n. 90, 13 maio 2013a. Seção 2, p. 12-14. Disponível em: <http://portal.mec. gov.br/index.php?option=com_docman\&view=download\&alias=13102-port389-13pdf\&category_slug=maio-2013-pdf\&Itemid=30192> . Acesso em: 7 set. 2017.

BRASIL. Ministério da Educação. Secretaria de Educação Continuada, Alfabetização, Diversidade e Inclusão. Edital de convocação n ${ }^{\circ} 2$, de 27 de agosto de 2013. Diário Oficial da União, Brasília, n. 167, 29 ago. 2013b. Seção 3, p. 81-84. Disponível em: $<$ http://pesquisa.in.gov.br/imprensa/jsp/visualiza/index.jsp?jornal=3\&pagina=81\&d ata=29/08/2013 $>$. Acesso em: 7 set. 2017. 
BRASIL. Ministério da Educação. Portaria $\mathrm{n}^{\circ}$ 52, de 24 de janeiro de 2014. Diário Oficial da União, Brasília, n. 18, 27 jan. 2014a. Seção 2, p. 10. Disponível em: <http:// pesquisa.in.gov.br/imprensa/jsp/visualiza/index.jsp?jornal=2\&pagina $=10 \& d$ ata=27/01/2014>. Acesso em: 7 set. 2017.

BRASIL. Presidência da República. Casa Civil. Subchefia para Assuntos Jurídicos. Lei $n^{0}$ 13.005, de 25 de junho de 2014. Aprova o Plano Nacional de Educação - PNE e dá outras providências. Brasília, 2014b. Disponível em: <http://www.planalto.gov.br/ ccivil_03/_ato2011-2014/2014/lei/113005.htm>. Acesso em: 7 set. 2014.

BRASIL. Ministério da Educação. Ministério da Educação desenvolve políticas e ações voltadas para povos indígenas. 18 abr. 2017. Disponível em: <http://portal.mec.gov.br/ index.php?option=com_content\&view=article\&id=47581:dia-do-indio\&catid=206> . Acesso em: 7 set. 2017.

BROOKE, N. O escritório da Fundação Ford no Brasil, 1962-2002. Um apanhado histórico. In: BROOKE, N.; WITOSHYNSKY, M. (Org.). Os 40 anos da Fundação Ford no Brasil: uma parceria para a mudança social (The Ford Foundation's 40 Years in Brazil: a partnership for social change). São Paulo: Edusp; Rio de Janeiro: Fundação Ford, 2002. p. 13-53.

BROOKE, N.; WITOSHYNSKY, M. (Org.). Os 40 anos da Fundação Ford no Brasil: uma parceria para a mudança social (The Ford Foundation's 40 Years in Brazil: a partnership for social change). São Paulo: Edusp; Rio de Janeiro: Fundação Ford, 2002.

CAMPOS, M. M. Da formação de professores à reforma da educação. In: BROOKE, N.; WITOSHYNSKY, M. (Org.). Os 40 anos da Fundação Ford no Brasil: uma parceria para a mudança social (The Ford Foundation's 40 Years in Brazil: a partnership for social change). São Paulo: Edusp; Rio de Janeiro: Fundação Ford, 2002. p. 97-127.

CAMPOS, M. M. et al. Fulvia Rosemberg (1942-2014). Cadernos de Pesquisa, São Paulo, v. 44, n. 153, p. 760-775, jul./set. 2014. Disponível em: <http://www.scielo.br/pdf/cp/ v44n153/a14v44n153.pdf>. Acesso em: 7 set. 2017.

CANÊDO, L. B. Les boursiers de la Fondation Ford et la recomposition des sciences sociales brésiliennes: le cas de la science politique. Cahiers de la recherche sur l'éducation et les saviors, Paris, hors-série, n. 2, p. 33-55, 2009. Disponível em: <http:// cres.revues.org/670>. Acesso em: 7 set. 2017.

CANÊDO, L. B. L'importation et l'exportation de stratégies de construction de savoirs et d'élites d'Etat: la Fondation Ford au Brésil. 2014. Disponível em: <https://leticiabcanedo. wordpress.com/2014/06/23/limportation-et-lexportation-de-strategies-de-construction-de-savoirs-et-delites-detat-la-fondation-ford-au-bresil/>. Acesso em: 7 set. 2017.

CANÊDO, L. B.; GARCIA JR., A. R. La formation à la recherche au Brésil et la concurrence mondialisée des agences de coopération scientifique. In: LECLERC-OLIVE, M.; SCARFO GHELLAR, G.; WAGNER, A.-C. (Dir.). Les mondes universitaires face au marché: circulation des savoirs et pratiques des acteurs. Paris: Karthala, 2011. p. 351-365. 
CAROSO, C.; LOSADA, R. Desafios para uma educação superior para os Povos Indígenas no Brasil. Relatório do seminário realizado em Porto Seguro, Bahia, 16 a 19 de maio de 2007. In: SOUZA LIMA, A. C. de; BARROSO, M. M. (Org.). O Projeto Trilhas de Conhecimentos e o ensino superior de indígenas no Brasil: uma experiência de fomento a ações afirmativas. Rio de Janeiro: E-papers, 2017. No prelo.

CASTILLO SALAZAR, A. PAEIIES: um programa de atención a jóvenes indígenas em universidades convencionales mexicanas. In: SOUZA LIMA, A. C. de; PALADINO, M. (Org.). Caminos hacia la educación superior: los Programas Pathways de la Fundación Ford para Pueblos indígenas em México, Peru Brasil y Chile. Rio de Janeiro: E-papers, 2012. p. 29-42. (Abrindo Trilhas, 1). Disponível em: <http://laced.etc.br/site/pdfs/ CaminosHaciaLaEducacionSuperior.pdf>. Acesso em: 7 set. 2017.

COLLET, C.; PALADINO, M.; RUSSO, K. Quebrando preconceitos: subsídios para o ensino das culturas e histórias dos povos indígenas. Rio de Janeiro: Contra Capa Livraria: Laced, 2014. (Série Traçados, v. 3). Disponível em: <http://laced.etc.br/site/ arquivos/Quebrando_preconceitos.pdf>. Acesso em: 7 set. 2017.

CORDEIRO, M. J. de J. A. Três anos de efetiva presença de negros e indígenas cotistas nas salas de aula da UEMS: primeiras análises. In: BRANDÃO, A. A. (Org.). Cotas raciais no Brasil: a primeira avaliação. Rio de Janeiro: DP\&A: LPP/UERJ, 2007. p. 87-114.

CORDEIRO, M. J. de J. A. Negros e indígenas cotistas da UEMS: desempenho acadêmico do ingresso à conclusão do curso. In: SOUZA LIMA, A. C. de; BARROSO, M. M. (Org.). Povos indígenas e universidade no Brasil: contextos e perspectivas, 2004-2008. Rio de Janeiro: E-papers, 2013. p. 241-271. (Abrindo Trilhas, 2). Disponível em: <http:// laced.etc.br/site/pdfs/LivroPovosIndigenas.pdf>. Acesso em: 7 set. 2017.

CUNHA, L. O. P. da. Participação na mesa: "Rumo ao Ensino Superior - o que houve, o que há e o que se espera que exista”. In: SOUZA LIMA, A. C. de; BARROSO-HOFFMAN, M. (Org.). Desafios para uma educação superior para os povos indígenas no Brasil: políticas públicas de ação afirmativa e direitos culturais diferenciados. Publicação do material referente ao seminário realizado em agosto de 2004. Rio de Janeiro: Museu Nacional/UFRJ/Laced, 2007. p. 99-101. Relatório técnico publicado. Disponível em: <http://www.trilhasdeconhecimentos.etc.br/livros/arquivos/Desafios.pdf>. Acesso em: 7 set. 2017.

DE PAULA, L. R. de; VIANNA, F. L. de B. Mapeando políticas públicas para povos indígenas: guia de ações federais. Rio de Janeiro: Contra Capa Livraria: Laced/Museu Nacional/UFRJ, 2011. (Série Traçados, v. 1). Disponível em: <http://laced.etc.br/site/ arquivos/mapeando.pdf>. Acesso em: 7 set. 2017.

DIDOU AUPETIT, S. (Coord.). Los programas de educación superior indígena en América Latina y en México: componentes tradicionales y emergentes. México: Unesco-Iesalc: Conalmex: OBSMAC, 2014. 
DIDOU AUPETIT, S.; GÉRARD, E. (Ed.). Fuga de cerebros, movilidad académica, redes científicas: perspectivas latino-americanas. México: Iesalc: Cinvestav: IRD, 2009.

DIDOU AUPETIT, S.; REMEDI ALLIONE, E. Programa de atención a estudiantes indígenas en educación superior en América Central: los sellos institucionales. México: Cinvestav: IPN: Juan Pablos, 2010.

EDUCAÇÃO superior de indígenas no Brasil: balanços de uma década e subsídios para o futuro. Rio de Janeiro: Laced/Museu Nacional-UFRJ, 2015. Vídeo documentário. Disponivel em: $<$ https://www.youtube.com/watch?v=bUz5bBMH-Lc\&feature=y outu.be>. Acesso em: 7 set. 2017.

FARIA, L.; COSTA, M. C. da. Cooperação científica internacional: estilos de atuação da Fundação Rockefeller e da Fundação Ford. Dados: Revista de Ciências Sociais, Rio de Janeiro, v. 49, n. 1, p. 159-191, 2006.

FERNANDES, M. L.; CARVALHO, F. A. de; REPETTO, M. Desafios da formação superior indígena: o Programa E'ma Pia de Acesso e Permanência de Indígenas no Ensino Superior, Insikiran/UFRR. In: SOUZA LIMA, A. C. de; BARROSO, M. M. (Org.). O Projeto Trilhas de Conhecimentos e o ensino superior de indígenas no Brasil: uma experiência de fomento a ações afirmativas. Rio de Janeiro: E-papers, 2017. No prelo.

FIALHO, M. H. S. S.; MENEZES, G. H.; RAMOS, A. R. O ensino superior e os povos indígenas; a contribuição da Funai para a constituição de políticas públicas. In: SOUZA LIMA, A. C. de; BARROSO, M. M. (Org.). Povos indígenas e universidade no Brasil: contextos e perspectivas, 2004-2008. Rio de Janeiro: E-papers, 2013. p. 109-118. (Abrindo Trilhas, 2). Disponível em: <http://laced.etc.br/site/pdfs/LivroPovosIndigenas.pdf>. Acesso em: 7 set. 2017.

FLORES, L. Centro Amazônico de Formação Indígena (CAFI). Coordenação das Organizações Indígenas da Amazônia Brasileira (COIAB). In: MATO, D. (Coord.). Instituciones interculturales de educación superior en América Latina: procesos de construcción: logros, innovaciones y desafíos. Caracas: IESALC-UNESCO, 2009. p. 103121. Disponível em: <http://unesdoc.unesco.org/images/0018/001856/185698s.pdf>. Acesso em: 7 set. 2017.

FRANCHETTO, B. Sobre discursos e práticas na educação escolar indígena. In: SOUZA LIMA, A. C. de; BARROSO-HOFFMANN, M. (Org.). Estado e povos indígenas: bases para uma nova política indigenista II. Rio de Janeiro: Contra Capa Livraria: Laced, 2002. p. 95-99. Disponível em: <http://laced.etc.br/site/acervo/livros/ estado-e-povos-indigenas-ii/>. Acesso em: 7 set. 2017.

FREITAS, A. E. de C. Intelectuais indígenas e a construção da universidade pluriétnica no Brasil: povos indígenas e os novos contornos do programa de educação tutorial/ conexões de saberes. Rio de Janeiro: E-papers, 2015. (Abrindo Trilhas, 4). 
GARNELO, L.; PONTES, A. L. (Org.). Saúde indígena: uma introdução ao tema. Brasília: MEC-SECADI, 2012. (Série Vias dos Saberes, 5; Coleção Educação para Todos, 38). Disponível em: <http://www.trilhasdeconhecimentos.etc.br/livros/arquivos/ ColET15_Vias05WEB.pdf>. Acesso em: 7 set. 2017.

GONZÁLEZ PLITT, M. E.; GONZÁLEZ GÓMEZ, Y. Inequidad educativa em estudiantes indígenas de Chile: el caso de los Mapuche. In: SOUZA LIMA, A. C. de; PALADINO, M. (Org.). Caminos hacia la educación superior: los Programas Pathways de la Fundación Ford para Pueblos indígenas em México, Peru Brasil y Chile. Rio de Janeiro: E-papers, 2012. p. 161-187. (Abrindo Trilhas, 1). Disponível em: <http://laced.etc.br/ site/pdfs/CaminosHaciaLaEducacionSuperior.pdf>. Acesso em: 7 set. 2017.

GOULART, A. C. Experimentar, contestar e refazer-se: caminhos de sonhos e enfrentamentos percorridos por acadêmicos Kaingang e Guarani na Universidade Estadual de Londrina - PR. 2014. Dissertação (Mestrado em Antropologia Social)-Setor de Ciências Humanas, Universidade Federal do Paraná, Curitiba, 2014.

GRUPIONI, L. D. B. Experiências e desafios na formação de professores indígenas no Brasil. Em Aberto, Brasília, v. 20, n. 76, p. 13-18, fev. 2003.

GRUPIONI, L. D. B. Impasses marcam a execução de políticas de educação. In: RICARDO, B.; RICARDO, F. (Org.). Povos indígenas no Brasil: 2006-2010. São Paulo: Instituto Socioambiental, 2011. p. 102-108.

GRUPIONI, L. D. B. Que educação diferenciada é essa?. In: RICARDO, B.; RICARDO, F. (Org.). Povos indígenas no Brasil: 2011-2016. São Paulo: Instituto Socioambiental, 2017. p. 111-113.

GUIMARÃES, S. G. A diversidade sociocultural nas políticas públicas educacionais. In: SOUZA LIMA, A. C. de; BARROSO, M. M. (Org.). Povos indígenas e universidade no Brasil: contextos e perspectivas, 2004-2008. Rio de Janeiro: E-papers, 2013. p. 195205. (Abrindo Trilhas, 2). Disponível em: <http://laced.etc.br/site/pdfs/LivroPovosIndigenas.pdf>. Acesso em: 7 set. 2017.

HENRIQUES, R. Desigualdade racial no Brasil: evolução das condições de vida na década de 90. Textos para Discussão, Rio de Janeiro, n. 807, 2001.

INFORME de la Conferencia Mundial contra el Racismo, la Discriminación Racial, la Xenofobia y las Formas Conexas de Intolerancia. Durban, 2001. Disponível em: <https://www.cepal.org/mujer/noticias/noticias/9/26089/InformeDurban.pdf>. Acesso em: 7 set. 2017.

INSTITUTO DE ESTUDOS E PESQUISAS EDUCACIONAIS ANÍSIO TEIXEIRA. Sinopse estatística da educação superior 2015. Brasília, 2016. planilha 1.10. Disponível em: <http:// download.inep.gov.br/informacoes_estatisticas/sinopses_estatisticas/sinopses_educacao_superior/sinopse_educacao_superior_2015.zip>. Acesso em: 7 set. 2017. 
JAUMONT, F. Strategic philanthropy, organizational legitimacy, and the development of higher education in Africa: the partnership for higher education in Africa (2000-2010). 2014. PhD Thesis. New York University, New York, 2014.

JUNGES, M. Antonio Brand (1950-2012). IHU, n. 398, 13 ago. 2012. Disponível em: <http://www.ihuonline.unisinos.br/artigo/4559-antonio-brand-(1950-2012)>. Acesso em: 7 set. 2017.

KANT DE LIMA, R. Entre as leis e as normas: éticas corporativas e práticas profissionais na segurança pública e na Justiça Criminal. Dilemas: Revista de Estudos de Conflito e Controle Social, v. 6, n. 3, p. 549-580, out./dez. 2013. Disponível em: <http:// www.ineac.uff.br/sites/default/files/library/files/artigo_kant_revista_dilemas_0. pdf $>$. Acesso em: 7 set. 2017.

LIMA, L. M. Cooperação e parceria no contexto de um projeto piloto: a experiência do PPTAL. In: SOUZA LIMA, A. C. de. Gestar e gerir: para uma antropologia da administração pública no Brasil. Rio de Janeiro: Nuap: Relume-Dumará, 2003. p. 147-198. Disponível em: <http://laced.etc.br/site/acervo/livros/gestar-e-gerir/>. Acesso em: 7 set. 2017.

LUCIANO-BANIWA, G. dos S. O indio brasileiro: o que você precisa saber sobre os povos indígenas no Brasil de hoje. Brasília: Ministério da Educação, Secretaria de Educação Continuada, Alfabetização e Diversidade: Laced/Museu Nacional, 2006. (Série Vias dos Saberes, 1; Coleção Educação Para Todos, 12). Disponível em: <http:// laced.etc.br/site/Trilhas/livros/arquivos/ColET12_Vias01WEB.pdf>. Acesso em: 7 set. 2017.

LUCIANO-BANIWA, G. J. dos S. Educação para o manejo do mundo: entre a escola ideal e a escola real no Alto Rio Negro. Rio de Janeiro: Contra Capa: Laced, 2013.

MAIA, M. Manual de lingüística: subsídios para a formação de professores indígenas na área de linguagem. Brasília: Ministério da Educação, Secretaria de Educação Continuada, Alfabetização e Diversidade: Laced/Museu Nacional, 2006. (Série Vias dos Saberes, 4; Coleção Educação Para Todos, 15). Disponível em: <http://laced.etc.br/ site/trilhas/livros/arquivos/ColET15_Vias04WEB.pdf>. Acesso em: 7 set. 2017.

MATOS, K. G. e. Educação escolar indígena. In: POLÍTICAS de qualidade na educação: um balanço institucional. Brasília: Ministério da Educação, Secretaria de Educação Fundamental, 2002. p. 235-283.

MATOS, K. G. e. Ensino superior e povos indígenas. In: SOUZA LIMA, A. C. de; BARROSO, M. M. (Org.). Povos indígenas e universidade no Brasil: contextos e perspectivas, 2004-2008. Rio de Janeiro: E-papers, 2013. p. 207-239. (Abrindo Trilhas, 2). Disponível em: <http://laced.etc.br/site/pdfs/LivroPovosIndigenas.pdf>. Acesso em: 7 set. 2017.

MICELI, S. (Org.). A Fundação Ford no Brasil. São Paulo: Sumaré: Fapesp, 1993. 
MICELI, S. A Fundação Ford e os cientistas sociais no Brasil, 1962-1992. In: MICELI, S. (Org.). História das ciências sociais no Brasil. São Paulo: Sumaré, 1995. v. 2, p. 341-395.

MUITA terra para pouco índio?. Direção: Bruno Pacheco de Oliveira. Produção executiva: Antonio Carlos de Souza Lima. Rio de Janeiro: Associação Brasileira de Antropologia: Laced/Museu Nacional-UFRJ, 2002. Vídeo documentário. Disponível em: <https://www.youtube.com/watch?v=wAh2nokq-iM>. Acesso em: 7 set. 2017.

OLIVEIRA, A. da C.; BELTRÃO, J. F. (Org.). Etnodesenvolvimento e universidade: formação acadêmica para povos indígenas e comunidades tradicionais. Belém: Santa Cruz, 2015.

OLIVEIRA, B. P. de. Mídia índio(s): comunidades indígenas e novas tecnologias de comunicação. Rio de Janeiro: Contra Capa: Laced, 2014. (Série Traçados, 4). Disponível em: <http://laced.etc.br/site/arquivos/Midia_indios.pdf>. Acesso em: 7 set. 2017.

OLIVEIRA, B. P. de. Quebra a cabaça e espalha a semente: desafios para um protagonismo indígena. Rio de Janeiro: E-Papers, 2015. Disponível em: <http://laced.etc.br/ site/arquivos/quebra_cabaca.pdf>. Acesso em: 7 set. 2017.

OLIVEN, R. G.; RIDENTI, M.; BRANDÃO, G. M. (Org.). A Constituição de 1988 na vida brasileira. São Paulo: Aderaldo \& Rothschild: Anpocs, 2008.

PACHECO DE OLIVEIRA, J. Terras Indígenas no Brasil: uma avaliação preliminar de seu reconhecimento preliminar e outras destinações sobrepostas. In: TERRAS Indígenas no Brasil. São Paulo: Centro Ecumênico de Documentação e Informação; Rio de Janeiro: Museu Nacional/UFRJ, 1987. p. 7-32. Disponível em: <http://laced.etc. br/site/pdfs/TERRASI1.PDF>. Acesso em: 7 set. 2017.

PACHECO DE OLIVEIRA, J. Indigenismo e territorialização: poderes, rotinas e saberes coloniais no Brasil contemporâneo. Rio de Janeiro: Contra Capa Livraria, 1998.

PACHECO DE OLIVEIRA, J. O ofício do etnógrafo e a responsabilidade social do cientista. In: PACHECO DE OLIVEIRA, J. Ensaios de antropologia histórica. Rio de Janeiro: Editora da UFRJ, 1999. p. 211-263.

PACHECO DE OLIVEIRA, J. A viagem da volta: etnicidade, política e reelaboração cultural no Nordeste indígena. 2. ed. Rio de Janeiro: Contra Capa Livraria, 2004.

PACHECO DE OLIVEIRA, J. Sem a tutela, uma nova moldura de nação. In: OLIVEN, R. G.; RIDENTI, M.; BRANDÃO, G. M. (Org.). A Constituição de 1988 na vida brasileira. São Paulo: Aderaldo \& Rothschild: Anpocs, 2008. p. 251-275.

PACHECO DE OLIVEIRA, J.; ROCHA FREIRE, C. A. da. A presença indígena na formação do Brasil. Brasília: Ministério da Educação, Secretaria de Educação Continuada, Alfabetização e Diversidade: Rio de Janeiro: Laced/Museu Nacional, 2006. (Série Vias dos Saberes, 2; Coleção Educação Para Todos, 13). Disponível em: <http://laced. etc.br/site/Trilhas/livros/arquivos/ColET13_Vias02WEB.pdf>. Acesso em: 7 set. 2017. 
PALADINO, M. Estudar e experimentar na cidade: trajetórias sociais, escolarização e experiência urbana entre 'Jovens' indígenas Ticuna, Amazonas. 2006. Tese (Doutorado em Antropologia Social)-Museu Nacional, Universidade Federal do Rio de Janeiro, Rio de Janeiro, 2006. Disponível em: <http://flacso.redelivre.org.br/ files/2012/07/391.pdf>. Acesso em: 7 set. 2017.

PALADINO, M.; ALMEIDA, N. P. Entre a diversidade e a desigualdade: uma análise das políticas públicas para a educação escolar indígena no Brasil dos governos Lula. Rio de Janeiro: Contra Capa Livraria: Laced/Museu Nacional/UFRJ, 2012. (Série Traçados, 2). Disponível em: <http://laced.etc.br/site/arquivos/Laced_Entre\%20a\%20 diversidade\%20e\%20a\%20desigualdade.pdf>. Acesso em: 7 set. 2017.

PALADINO, M.; GARCÍA, S. (Org.). Educación escolar indígena: investigaciones antropológicas en Brasil y Argentina. Buenos Aires: Antropofagia, 2007.

PAULINO, M. M. Povos indigenas e ações afirmativas o caso do Paraná. 2008. Dissertação (Mestrado em Educação)-Faculdade de Educação, Universidade Federal do Rio de Janeiro, Rio de Janeiro, 2008.

PAULINO, M. M. Ações afirmativas para indígenas no Paraná. In: SOUZA LIMA, A. C. de; BARROSO, M. M. (Org.). Povos indigenas e universidade no Brasil: contextos e perspectivas, 2004-2008. Rio de Janeiro: E-papers, 2013. p. 273-306. (Abrindo Trilhas, 2). Disponível em: <http://laced.etc.br/site/pdfs/LivroPovosIndigenas.pdf >. Acesso em: 7 set. 2017.

PAULINO, M. M. Mais de uma década da primeira política de ação afirmativa para povos indígenas: novos elementos para debate. In: SOUZA LIMA, A. C. de (Org.). A educação superior de indígenas no Brasil: balanços e perspectivas. Rio de Janeiro: E-papers, 2016. p. 123-149. (Abrindo Trilhas, 5). Disponível em: <http://laced.etc.br/ site/pdfs/LEDSUPIND001.pdf>. Acesso em: 7 set. 2017.

PERIA, M. E. Ação afirmativa: um estudo sobre a reserva de vagas para negros nas universidades públicas brasileiras: o caso do Rio de Janeiro. 2004. Dissertação (Mestrado em Antropologia Social)-Museu Nacional, Universidade Federal do Rio de Janeiro, Rio de Janeiro, 2004.

PISA ligeiro. Direção: Bruno Pacheco de Oliveira. Produção e roteiro: João Pacheco de Oliveira. Rio de Janeiro: Laced/Museu Nacional-UFRJ, 2004. Vídeo documentário. Disponível em: <https://www.youtube.com/watch?v=FseTLA9D4jg>. Acesso em: 7 set. 2017.

RICARDO, B.; RICARDO, F. (Org.). Povos indigenas no Brasil: 2006-2010. São Paulo: Instituto Socioambiental, 2011. 
RICARDO, B.; RICARDO, F. (Org.). Povos indígenas no Brasil: 2011-2016. São Paulo: Instituto Socioambiental, 2017.

ROCHA, E. S. S. Contribuições da Fundação Ford à formação e consolidação de campos científicos no Brasil. InCID: Revista de Ciência da Informação e Documentação, Ribeirão Preto, v. 7, n. 2, p. 93-117, set. 2016/fev. 2017.

ROSEMBERG, F. Ação afirmativa na pós-graduação: o Programa Internacional de Bolsas da Fundação Ford na Fundação Carlos Chagas. São Paulo: FCC/SEP, 2013.

ROSEMBERG, F.; ANDRADE, L. F. Indígenas no Programa Internacional de Bolsas de Pós-Graduação da Fundação Ford e os aportes do Trilhas de Conhecimentos. In: SOUZA LIMA, A. C. de; BARROSO, M. M. (Org.). Povos indígenas e universidade no Brasil: contextos e perspectivas, 2004-2008. Rio de Janeiro: E-papers, 2013. p. 133-162. (Abrindo Trilhas, 2). Disponível em: <http://laced.etc.br/site/pdfs/LivroPovosIndigenas.pdf>. Acesso em: 7 set. 2017.

RUSSO, K. O Observatório da Educação Escolar Indígena e a relação entre universidades e comunidades indígenas no desenvolvimento da educação intercultural: uma análise a partir do Edital 01/2009 Capes/Secadi/Inep. In: SOUZA LIMA, A. C. de (Org.). A educação superior de indígenas no Brasil: balanços e perspectivas. Rio de Janeiro: E-papers, 2016. p. 63-93. (Abrindo Trilhas, 5). Disponível em: <http://laced. etc.br/site/pdfs/LEDSUPIND001.pdf>. Acesso em: 7 set. 2017.

SEMINÁRIO Bases para uma Nova Política Indigenista. Rio de Janeiro: Museu Nacional, Universidade Federal do Rio de Janeiro, 1999. Relatório. Disponível em: <http://laced.etc.br/site/pdfs/RelFinal2.pdf>. Acesso em: 7 set. 2017.

SILVA, M. A. da. Entrevista com Antonio Jacó Brand. Tellus, Campo Grande, ano 12, n. 23, p. 179-192, jul./dez. 2012. Disponível em: <http://www.tellus.ucdb.br/index. php/tellus/article/view/267/167>. Acesso em: 7 set. 2017.

SILVA, R. H. D. da. O Estado brasileiro e a educação (escolar) indígena: um olhar sobre o plano nacional de educação. Tellus, Campo Grande, ano 2, n. 2, p. 123-136, abr. 2002. Disponível em: <http://tellus.ucdb.br/index.php/tellus/article/view/15/25>. Acesso em: 7 set. 2017.

SILY, P. R. M. Casa da ciência, casa da educação: ações educativas do Museu Nacional (1818-1835). 2012. Tese (Doutorado em Educação)-Faculdade de Educação, Universidade do Estado do Rio de Janeiro, Rio de Janeiro, 2012.

SOUSA, C. N. I. de.Projetos indígenas focados em atividades econômicas: panorama geral da experiência do PDPI. In: SOUSA, C. N. I. de et al. (Org.). Povos indigenas: projetos e desenvolvimento. Rio de Janeiro: Contra Capa Livraria, 2007. p. 37-64. Disponível em: <http://laced.etc.br/site/acervo/livros/povos-indigenas/>. Acesso em: 7 set. 2017. 
SOUSA, C. N. I. de; ALMEIDA, F. V. R. de (Org.). Gestão territorial em terras indígenas no Brasil. Brasília: Ministério da Educação, Secretaria de Educação Continuada, Alfabetização, Diversidade e Inclusão: Unesco, 2013. (Série Vias dos Saberes, 6; Coleção Educação para Todos, 39). Disponível em: <http://laced.etc.br/site/arquivos/ViaDosSaberes_Gestao.pdf >. Acesso em: 7 set. 2017.

SOUSA, C. N. I. de et al. (Org.). Povos indígenas: projetos e desenvolvimento. Rio de Janeiro: Contra Capa Livraria, 2007. Disponível em: <http://laced.etc.br/site/acervo/ livros/povos-indigenas/>. Acesso em: 7 set. 2017.

SOUSA, C. N. I. de et al. (Org.). Povos indígenas: projetos e desenvolvimento, II. Brasília: Paralelo 15; Rio de Janeiro: Laced, 2010. Disponível em: <http://laced.etc.br/site/ acervo/livros/povos-indigenas-ii/>. Acesso em: 7 set. 2017.

SOUZA, H. C. de. Educação superior para indígenas no Brasil (mapeamento provisório). Tangará da Serra: Unemat: IESALC, 2003.

SOUZA LIMA, A. C. de. Um grande cerco de paz: poder tutelar, indianidade e formação do Estado no Brasil. Petrópolis: Vozes, 1995.

SOUZA LIMA, A. C. de. Problemas de qualificação de pessoal para novas formas de ação indigenista. In: SOUZA LIMA, A. C. de; BARROSO-HOFFMANN, M. (Org.). Estado e povos indígenas: bases para uma nova política indigenista II. Rio de Janeiro: Contra Capa Livraria: Laced, 2002. p. 83-94. Disponível em: <http://laced.etc.br/site/ acervo/livros/estado-e-povos-indigenas-ii/>. Acesso em: 7 set. 2017.

SOUZA LIMA, A. C. de. Educação superior de indígenas no Brasil - sobre cotas e algo mais. In: BRANDÃO, A. A. (Org.). Cotas raciais no Brasil: a primeira avaliação. Rio de Janeiro: DP\&A: LPP/UERJ, 2007. p. 253-279.

SOUZA LIMA, A. C. de. Trilhas de conhecimentos: o ensino superior de indígenas no Brasil: uma experiência de fomento a ações afirmativas de Roraima. In: MATO, D. (Coord.). Diversidad cultural e interculturalidad en educación superior. Caracas: IESALCUNESCO, 2008. p. 167-176. Disponível em: <http://www.iesalc.unesco.org.ve/images/ stories/brasil.pdf>. Acesso em: 7 set. 2017.

SOUZA LIMA, A. C. de. Povos indígenas no Brasil contemporâneo: de tutelados a "organizados"?. In: SOUSA, C. N. I. de et al. (Org.). Povos indígenas: projetos e desenvolvimento, II. Brasília: Paralelo 15; Rio de Janeiro: Laced, 2010. p. 15-50. Disponível em: <http://laced.etc.br/site/arquivos/O3-Povos-II.pdf>. Acesso em: 7 set. 2017.

SOUZA LIMA, A. C. de. A participação indígena no contexto dos governos Lula. In: RICARDO, B.; RICARDO, F. (Org.). Povos indígenas no Brasil: 2006-2010. São Paulo: Instituto Socioambiental, 2011. p. 91-98. 
SOUZA LIMA, A. C. de. Indígenas e ações afirmativas: as cotas bastam?. Cadernos de Pensamento Crítico Latino-Americano, Rio de Janeiro, v. 31, out. 2012, p. 22-23.

SOUZA LIMA, A. C. de. Cenários da educação Superior de indígenas no Brasil, 20042008: as bases e diálogos do Projeto Trilhas de Conhecimento. In: SOUZA LIMA, A. C. de; BARROSO, M. M. (Org.). Povos indígenas e universidade no Brasil: contextos e perspectivas, 2004-2008. Rio de Janeiro: E-papers, 2013. p. 15-44. (Abrindo Trilhas, 2). Disponível em: <http://laced.etc.br/site/pdfs/LivroPovosIndigenas.pdf>. Acesso em: 7 set. 2017.

SOUZA LIMA, A. C. de (Org.). A educação superior de indígenas no Brasil: balanços e perspectivas. Rio de Janeiro: E-papers, 2016. (Abrindo Trilhas, 5). Disponível em: <http://laced.etc.br/site/pdfs/LEDSUPIND001.pdf>. Acesso em: 7 set. 2017.

SOUZA LIMA, A. C. de. Povos indígenas na universidade: avanços e desafios. In: RICARDO, B.; RICARDO, F. (Org.). Povos indigenas no Brasil: 2011-2016. São Paulo: Instituto Socioambiental, 2017. p. 114-117.

SOUZA LIMA, A. C. de; BARROSO, M. M. (Org.). Povos indigenas e universidade no Brasil: contextos e perspectivas, 2004-2008. Rio de Janeiro: E-papers, 2013a. (Abrindo Trilhas, 2). Disponível em: <http://laced.etc.br/site/pdfs/LivroPovosIndigenas.pdf>. Acesso em: 7 set. 2017.

SOUZA LIMA, A. C. de; BARROSO, M. M. A presença indígena na construção de uma educação superior universal, diferenciada e de qualidade. In: SOUZA LIMA, A. C. de; BARROSO, M. M. (Org.). Povos indígenas e universidade no Brasil: contextos e perspectivas, 2004-2008. Rio de Janeiro: E-papers, 2013b. p. 45-77. (Abrindo Trilhas, 2). Disponível em: <http://laced.etc.br/site/pdfs/LivroPovosIndigenas.pdf>. Acesso em: 7 set. 2017.

SOUZA LIMA, A. C. de; BARROSO, M. M. (Org.). O Projeto Trilhas de Conhecimentos e o ensino superior de indigenas no Brasil: uma experiência de fomento a ações afirmativas. Rio de Janeiro: E-papers, 2017. No prelo.

SOUZA LIMA, A. C. de; BARROSO-HOFFMANN, M. (Org.). Além da tutela: bases para uma nova política indigenista, III. Rio de Janeiro: Contra Capa: Laced, 2002a. Disponível em: <http://laced.etc.br/site/acervo/livros/alem-da-tutela-iii/>. Acesso em: 7 set. 2017.

SOUZA LIMA, A. C. de; BARROSO-HOFFMANN, M. (Org.). Etnodesenvolvimento e políticas públicas: bases para uma nova política indigenista. Rio de Janeiro: Contra Capa Livraria: Laced, 2002b. Disponível em: <http://laced.etc.br/site/acervo/livros/ etnodesenvolvimento-e-polit/>. Acesso em: 7 set. 2017.

SOUZA LIMA, A. C. de; BARROSO-HOFFMANN, M. (Org.). Estado e povos indígenas: bases para uma nova política indigenista II. Rio de Janeiro: Contra Capa Livraria: Laced, 2002c. p. 83-94. Disponível em: <http://laced.etc.br/site/acervo/livros/ estado-e-povos-indigenas-ii/>. Acesso em: 7 set. 2017. 
SOUZA LIMA, A. C. de; BARROSO-HOFFMAN, M. (Org.). Desafios para uma educação superior para os povos indígenas no Brasil: políticas públicas de ação afirmativa e direitos culturais diferenciados. Publicação do material referente ao seminário realizado em agosto de 2004. Rio de Janeiro: Museu Nacional/UFRJ/Laced, 2007. Relatório técnico publicado. Disponível em: <http://www.trilhasdeconhecimentos. etc.br/livros/arquivos/Desafios.pdf>. Acesso em: 7 set. 2017.

SOUZA LIMA, A. C. de; PALADINO, M. (Org.). Caminos hacia la educación superior: los Programas Pathways de la Fundación Ford para Pueblos indígenas em México, Peru Brasil y Chile. Rio de Janeiro: E-papers, 2012a. (Abrindo Trilhas, 1). Disponível em: <http://laced.etc.br/site/pdfs/CaminosHaciaLaEducacionSuperior.pdf>. Acesso em: 7 set. 2017.

SOUZA LIMA, A. C. de; PALADINO, M. De sendas y caminos. Repensando experiencias de educación superior de indígenas en países de América Latina. In: SOUZA LIMA, A. C. de; PALADINO, M. (Org.). Caminos hacia la educación superior: los Programas Pathways de la Fundación Ford para Pueblos indígenas em México, Peru Brasil y Chile. Rio de Janeiro: E-papers, 2012b. p. 10-28. (Abrindo Trilhas, 1). Disponível em: <http:// laced.etc.br/site/pdfs/CaminosHaciaLaEducacionSuperior.pdf>. Acesso em: 7 set. 2017.

SOUZA LIMA, A. C. de et al. A administração pública e os povos indígenas. In: FALEIROS, V. de P. et al. (Org.). A era FHC e o governo Lula: transição?. Brasília: Instituto de Estudos Socioeconômicos, 2004. p. 293-326.

TRILHAS de conhecimento. Direção: Bruno Pacheco de Oliveira. Produção executiva: Antonio Carlos de Souza Lima. Rio de Janeiro: Laced/Museu Nacional-UFRJ, 2007. Vídeo documentário. Disponível em: <https://www.youtube.com/ watch?v=PAjJaXOObtY>. Acesso em: 7 set. 2017.

UNIVERSIDADE DO ESTADO DE MATO GROSSO. Faculdade Intercultural Indígena. Histórico. 2016. Disponível em: <http://indigena.unemat.br/institucional/historico/>. Acesso em: 7 set. 2017.

VALENTE, R. C. Conceitos e metodologias de desenvolvimento social da GTZ e projetos para povos indígenas no Brasil: reflexões de um processo de larga escala. In: SOUSA, C. N. I. de et al. (Org.). Povos indigenas: projetos e desenvolvimento. Rio de Janeiro: Contra Capa Livraria, 2007. p. 113-135. Disponível em: <http://laced.etc.br/ site/acervo/livros/povos-indigenas/>. Acesso em: 7 set. 2017.

VALENTE, R. C. A GTZ no Brasil: uma etnografia da cooperação alemã para o desenvolvimento. Rio de Janeiro: E-papers, 2010.

VESTIBULAR dos Povos Indígenas tem inscrições prorrogadas. G1 PR, 31 jul. 2017. Disponível em: <https://gl.globo.com/pr/parana/noticia/vestibular-dos-povos-indigenas-tem-inscricoes-prorrogadas.ghtml>. Acesso em: 7 set. 2017. 
VIANNA, F. de L. B. et al. Indígenas no ensino superior: as experiências do programa Rede de Saberes, em Mato Grosso do Sul. Rio de Janeiro: E-Papers, 2014. (Abrindo Trilhas, 3). Disponível em: <http://laced.etc.br/site/pdfs/LINDES001.pdf>. Acesso em: 7 set. 2017.

VIANNA JR., A. Prefácio. In: OLIVEIRA, A. da C.; BELTRÃO, J. F. (Org.). Etnodesenvolvimento e universidade: formação acadêmica para povos indígenas e comunidades tradicionais. Belém: Santa Cruz, 2015. p. v-xiv.

WEBER, M. Economía y sociedade. México: Fondo de Cultura Económica, 1983.

Recebido: 31/08/2017 Aceito: 10/09/2017 | Received: 8/31/2017 Accepted: 9/10/2017 